\title{
57. SUMMARY OF RESULTS OF BLACK SEA DRILLING
}

\author{
David A. Ross, Woods Hole Oceanographic Institution, Woods Hole, Massachusetts
}

\section{INTRODUCTION}

The Black Sea, which is one of the largest of the world's marginal seas, is unique in several ways. It is a semienclosed basin almost completely surrounded by large alpine mountain ranges: the Pontic mountains to the south and the Caucasus mountains to the east and north (Figure 1). Geophysical studies have shown that the Black Sea may contain as much as $17 \mathrm{~km}$ of material, which is probably of sedimentary origin, above a basaltic basement. It appears, therefore, that the area has been a sedimentary basin for a considerable period of time-general estimates are for as long as 200 million years, or back into Cretaceous time. Prior to then, the Black Sea area was probably a topographic high supplying sediments to surrounding marginal troughs that were eventually uplifted to form the now surrounding mountain ranges.

At present, the Black Sea has a very narrow and shallow connection, the Bosporus, to the Atlantic via the Mediterranean. The sill depth at the Bosporus is only about 50 meters, and the resulting restricted water circulation has helped cause the present anoxic conditions in the basin. The anoxic conditions show that the basin has undergone rather dramatic environmental changes, particularly in response to sea-level changes. Piston cores show that the environment changed from a lacustrine to an almost marine basin after the most recent rise in sea level. These recent changes have been documented clearly by numerous sedimentological, geochemical, and paleontological studies (see Degens and Ross, 1974, and papers therein). Prior sea-level changes and past connections with other basins would likewise have had a decisive influence on the sediments, water chemistry, and biological population of the Black Sea. As sea-level changes are climatically controlled, the geochemical and paleontological data from the Black Sea sediments can be used to establish the paleoclimatological and paleoecological record of this area as well as elucidating past worldwide sea-level changes. The relatively dramatic and rapid changes in the environmental setting of the Black Sea, combined with its high sedimentation rate, make it an especially good candidate for learning more about past changes in the world's environment and climate.

The principal objectives for drilling in the Black Sea fell into two major categories: those relative to stratigraphy and biostratigraphy, and those related to geochemistry. Among the former were: to obtain as complete as possible a Pleistocene stratigraphic and biostratigraphic section; to study the interactions between the Black Sea and the Mediterranean, and how they affect the sediments and reflect past sea-level changes. The main objectives of the geochemical program were to study diagenetic changes, particularly the formation of hydrocarbons and the degradation of amino

\footnotetext{
${ }^{1}$ Contribution 4025, Woods Hole Oceanographic Institution, Woods Hole, Massachusetts.
}

acids, carbohydrates, and porphyrins. In addition, we hoped to observe the initiation of catagenesis, a process which begins in the upper portion of the sediment column, a part that generally is not sampled in detail during oil well drilling.

Three sites were drilled in the Black Sea (Figure 1). The pertinent site data are given in Table 1. Because of the relatively high amounts of organic matter in the Recent sediments, and the possibility of high hydrocarbon and gas content at depth, all three sites were continuously cored. Many of the cores were gassy, to the degree that sediment was forcibly extruded from the core barrel when the core reached the deck. Gas content was monitored from all cores; butylane and propane were detected in Cores 31 and 32 from Hole 379A, but the methane/ethane ratio stayed within safety limits. Many of the cores eventually developed void areas because of the expanding gas; however, the firmness of the sediment and the care taken by the drilling crew permitted a good recovery ratio of $61 \%$.

\section{GENERAL ASPECTS OF THE THREE SITES}

It was thought that Site 379 , situated in the central portion of the Black Sea, would give the best opportunity for a complete Pleistocene stratigraphic and biostratigraphic section. Shortly after drilling the first few hundred meters, however, it became evident that the high sedimentation rate at this site would not permit us to penetrate the complete Pleistocene section within the time available. It was estimated that more than a kilometer of sediments overlay the Pliocene. This aspect, and the increasing occurrence of turbidites, led us to abandon this hole at a depth of 622 meters, and attempt a site nearer the flanks of the basin where the sedimentary sequences were thinner.

At Site 380 two holes were drilled. The first had to be abandoned because of an injury to a roughneck; the second (380A) was situated near the first and essentially continued the drilling where the first had stopped. Hole $380 \mathrm{~A}$ eventually had to be abandoned because an increase in pore pressure suggested a collapse of shales higher up in the section. The decision to abandon Site 379 and drill Site 380 proved to be a valid one in that there we obtained a Pleistocene as well as Pliocene section and terminated the hole in Miocene sediments.

Problems at Site 380 left us with a short period of time to do another site, and we picked one upslope from Site 380 where unconformities and a thinner sedimentary section were evident. Site 381 was continuously cored to $\mathbf{5 0 3 . 5}$ meters. Our anticipation of unconformities and missing sections from 381 was confirmed, and the strategy we used was successful in that we obtained apparently the oldest sediment (Miocene) yet from the Black Sea. Also of interest at this site was the presence of material indicating extremely shallow-water, perhaps even aerial, conditions during the past.

One of the major problems in the Black Sea drilling has been the establishment of a consistent and uniform stratig- 


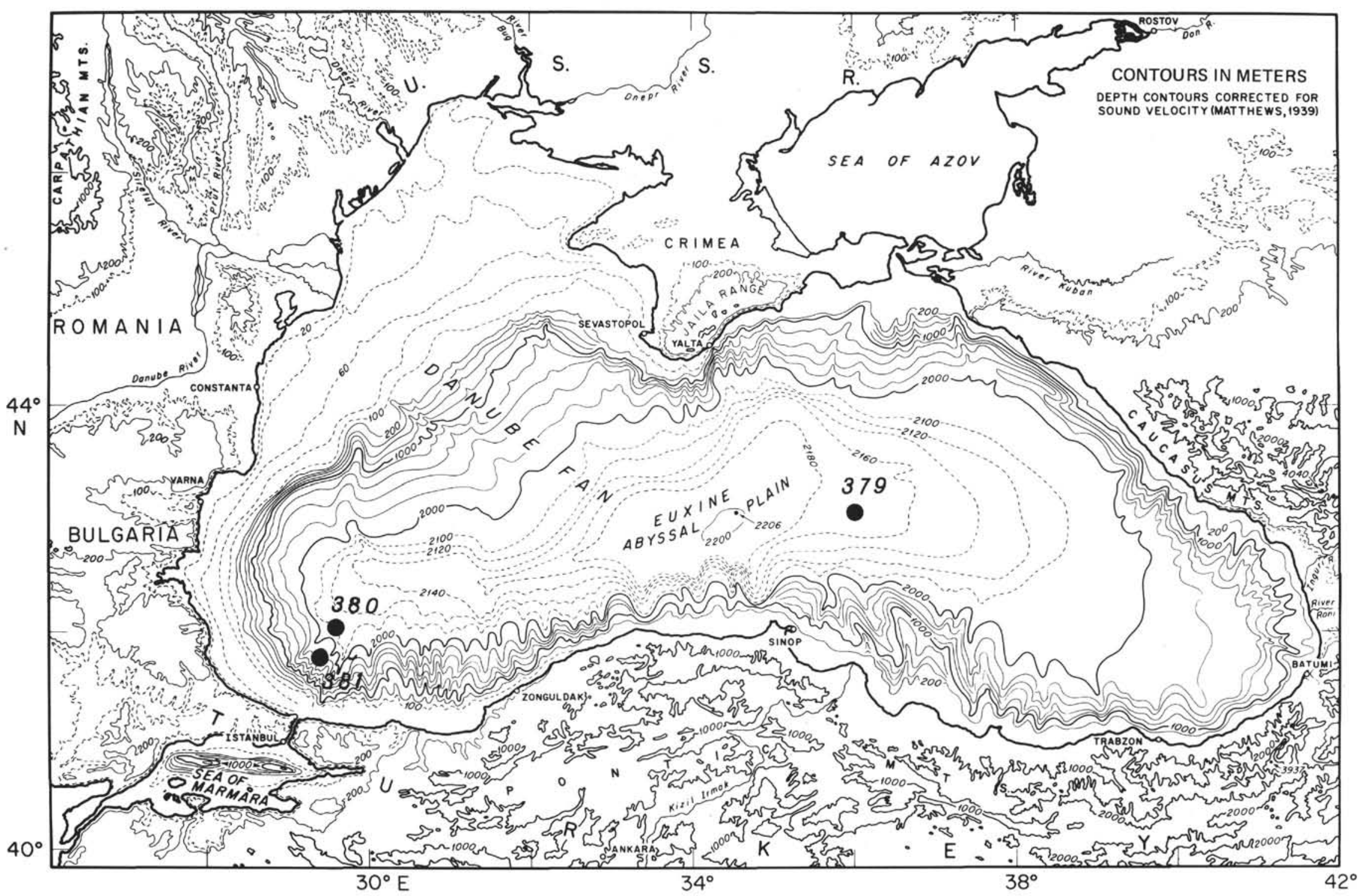

Figure 1. General bathymetry of the Black Sea, relief of surrounding areas, and location of Leg $42 B$ drill sites. Note change in contour interval at 200 meters and 2000 meters. (Bathymetry from Ross et al., 1974a). 
TABLE 1

Coring Data Leg 42B

\begin{tabular}{lccccrrrr}
\hline Hole & Latitude & Longitude & $\begin{array}{c}\text { Water } \\
\text { Depth } \\
(\mathrm{m})\end{array}$ & $\begin{array}{c}\text { Penetration } \\
(\mathrm{m})\end{array}$ & $\begin{array}{c}\text { No. of } \\
\text { Cores }\end{array}$ & $\begin{array}{c}\text { Meters } \\
\text { Cored }\end{array}$ & $\begin{array}{c}\text { Meters } \\
\text { Recovered }\end{array}$ & $\begin{array}{c}\% \\
\text { Recovery }\end{array}$ \\
\hline 379 & $43^{\circ} 00.29^{\prime}$ & $36^{\circ} 00.68^{\prime}$ & 2171 & 7.0 & 1 & 7.0 & 4.0 & 57.0 \\
$379 \mathrm{~A}$ & $43^{\circ} 00.29^{\prime}$ & $36^{\circ} 00.68^{\prime}$ & 2171 & 624.5 & 68 & 622.0 & 381.0 & 61.3 \\
$379 \mathrm{~B}$ & $43^{\circ} 00.29^{\prime}$ & $36^{\circ} 00.68^{\prime}$ & 2171 & 159.0 & 9 & 80.5 & 29.3 & 36.4 \\
380 & $42^{\circ} 05.98^{\prime}$ & $29^{\circ} 36.90^{\prime}$ & 2115 & 370.5 & 40 & 370.5 & 169.5 & 45.7 \\
$380 \mathrm{~A}$ & $42^{\circ} 05.94^{\prime}$ & $29^{\circ} 36.82^{\prime}$ & 2115 & 1073.5 & 79 & 734.5 & 421.5 & 57.4 \\
381 & $41^{\circ} 40.25^{\prime}$ & $29^{\circ} 24.96^{\prime}$ & 1750.5 & 503.5 & 54 & 503.5 & 269.5 & 53.5 \\
Total & & & & 2738.0 & 251 & 2318.0 & 1274.8 & 55.0 \\
\hline
\end{tabular}

raphy for the sediments from the three sites. It appears as if the agreement on such a stratigraphy is impossible for several reasons. The first includes the general absence of major paleontological age markers due to the short period of geological time that the cores cover, the rapidly varying environmental conditions that appear to leave a more dramatic mark on the floral and faunal composition than evolution, the general lack of preservation of many forms, the general absence of taxonomical knowledge of some of the forms, and reworking of older forms into the sediment.

A second reason for the complexity in developing a consistent and uniform stratigraphy is the lack of agreement among the participating scientists as to which correlation scheme should be used. As discussed in an earlier paper in this volume (Ross, this volume), both European and Black Sea correlation schemes have been used, as well as modified variations of each. In addition, there is a difference of opinion among scientists of which age to assign the sedimentary units. This varied opinion is most evident between those who worked on Sites 379 and 381 , as compared to those who worked on Site 380 . The numbering systems for these sites are different and, unfortunately, some shore-based workers have changed these numbers or introduced new systems of their own. What I have done in this article is use the nomenclature that the individual authors have used (or refer to core number when possible). I also give summary tables (in a later section) that should be of some assistance in resolving the problems of stratigraphy.

\section{Site 379}

The sedimentary section obtained at Site 379 can be divided into nine units (Table 2). These sediments are essentially of terrigenous origin, being mainly muds with occasional interbeds of silts, sandy silts, and sands. Some beds are coarse grained and graded, indicating deposition from turbidity currents. The entire sequence is of Pleistocene age. For more details of the sediments of this and other sites, the appropriate site report should be consulted.

The fauna and flora from Site 379 were generally not useful for dating purposes, but did indicate environmental changes. Pollen and spores were used to establish a ratio based on the presence of cold/dry forms to warm/moist forms (Steppe to Forest Index). The results of this work are discussed in more detail in a later section of this paper. Coccoliths and nannofossils could, in some instances, be used to establish marine or non-marine conditions. Diatoms, though not as abundant as anticipated, were also very useful for environmental changes and for correlations among the different sites.
Most of the cores had high gas content and contained biogenetic methane and carbon dioxide. A trace of hydrogen sulfide was noted in some of the shallower cores from this site, but was not detected at depth. When the cores were brought to the surface, gas pockets and expansion made difficult measurements of some physical properties, such as porosity, sound velocity, and wet bulk density.

Pore fluids from sediments of Site 379 generally were fresh to brackish in the upper 400 meters and tended to increase in salinity with depth. Several cycles were observed within the upper fresh-water section, and may correspond to marine episodes. Another observation of the pore fluids was that in the lower part of Site 379 , salinity increased to a value (about $40.5 \%$ ) higher than the present Black Sea bottom water or Mediterranean water. This suggested the presence of an evaporite deposit or hypersaline conditions at depth; the latter seems more probable (see Inorganic Geochemistry section of this paper).

Physical properties were difficult to determine and evaluate because of the previously mentioned high gas content, but water content and thermal conductivity data probably are still valid. Water content showed a decrease with depths from a maximum value of about 35 weight percent near the surface to about 20 weight percent at 622 meters. Thermal conductivity values were variable and showed no distinct trend with depth. Twelve down-hole temperature measurements were made at this site and anomalously high temperatures were recorded at two of them (45 $\mathrm{m}$ and 149.5 $\mathrm{m})$, which may be due to a chemical reaction. The average heat flow for this site is $0.94 \times 10^{6} \mathrm{cal} / \mathrm{cm}^{2} \mathrm{sec}$ (with a standard deviation of \pm 0.10 ).

Some of the seismic reflectors (obtained with a 10 in. ${ }^{3}$ and 40 in. $^{3}$ airgun) noted at this site appear correlative with sedimentological units and with bulk density.

\section{Site 380}

The sedimentary sequence at Site 380 was divided into five principal units with several subunits (Table 3 ). The deepest sediments appear to be of Miocene age. Subunits Ia, $\mathrm{Ib}$, and Ic are equivalent to Units 1, 2, and 3 from Site 379. The upper part of this sequence is correlative to Site 379 , and is principally of terrigenous origin; however, the lower 600 to 700 meters are mainly of chemical origin. Among the more interesting sediments were those that have high amounts of carbonate intercalations. These are called seekreide because of their general similarity to sediments found in some modern Swiss lakes. The Swiss term comes from the combination of the word "see," which means lake, and "kreide," which means chalk. These deposits also contain 
TABLE 2

Stratigraphic Units From Site 379

\begin{tabular}{|c|c|c|c|c|}
\hline Unit & $\begin{array}{l}\text { Thickness } \\
(\mathrm{m})\end{array}$ & $\begin{array}{l}\text { Interval } \\
(\mathrm{m})\end{array}$ & Cores & General Characteristics \\
\hline 1 & 0.30 & $0-0.30$ & - & $\begin{array}{l}\text { Nannofossil ooze composed mainly of } \\
\text { coccolith ooze Emiliania huxleyi - des- } \\
\text { cribed from piston cores }\end{array}$ \\
\hline 2 & 0.40 & $0.30-0.70$ & - & $\begin{array}{l}\text { Sapropel (known from piston cores) } \\
\text { deposited from about } 7000 \text { to } 3000 \\
\text { years B.P. }\end{array}$ \\
\hline 3 & 65 & $0.70-65$ & $1-7$ & $\begin{array}{l}\text { Terrigenous mud including some turbidites, } \\
\text { some fresh-water diatoms; cold climate } \\
\text { based on pollen }\end{array}$ \\
\hline 4 & 35 & $65-100$ & $8-11$ & $\begin{array}{l}\text { Diatomaceous nannofossil mud, some } \\
\text { marine diatoms and coccoliths; pollen } \\
\text { suggests warm climate }\end{array}$ \\
\hline 5 & 0.30 & 100 & 11 & $\begin{array}{l}\text { Sapropel; nannofossils indicate } \\
\text { brackish-water conditions }\end{array}$ \\
\hline 6 & 125.5 & $100-225$ & $12-24$ & $\begin{array}{l}\text { Terrigenous mud with some fresh-water } \\
\text { diatoms, but also some marine; } \\
\text { pollen suggests cold conditions }\end{array}$ \\
\hline 7 & $\sim 47$ & $\sim 225-273$ & $25-29$ & $\begin{array}{l}\text { Diatomaceous nannofossil mud, some } \\
\text { structureless carbonate layers } \\
\text { termed seekreide; fossils indicate } \\
\text { brackish marine conditions; pollen } \\
\text { indicate warm conditions }\end{array}$ \\
\hline 8 & $\sim 180$ & $\sim 273-453$ & $30-49$ & $\begin{array}{l}\text { Terrigenous mud similar to Units } 3 \\
\text { and } 6 \text {, some turbidites; pollen indicates } \\
\text { cold at top, warmer below Core } 43\end{array}$ \\
\hline 9 & 170 & $453-624.5$ & $50-69$ & $\begin{array}{l}\text { Terrigenous mud with carbonate } \\
\text { varves; pollen suggests more or } \\
\text { less warm climate }\end{array}$ \\
\hline
\end{tabular}

some large slump masses that apparently are not due to drilling operations; slumping is often a common feature in Seekreide deposits. Some of the Seekreide is varved and may be of annual origin; other larger scaled layering may represent longer trends, such as climate.

Subunit IVD is a coarse clastic stromatolitic dolomite, which apparently was formed in an intertidal or supratidal environment. Thus, this site, though presently covered by over 2000 meters of water and buried by 860 meters or so of sediment, was very near sea level at the time of deposition. Site 380 gave us our most complete sedimentary section from the Black Sea.

As with Site 379, shipboard analyses of fauna and flora were not very useful in determining age of the sediments, but indicated environmental changes. The principal biological components were diatoms, pollen, and spores.

Methane was present in most of the samples from Site 380; ethane was present in trace amounts in the near surface cores and tended to decrease with depth. Interstitial fluids also showed the upper fresh-water section as noted from Site 379 , but it was considerably more attenuated. With depth, interstitial waters showed a smooth salinity increase, reaching $98 \%$, suggesting that an older hypersaline stage may have existed in the Black Sea, but not necessarily accompanied by actual formation of evaporites. Mass physical properties still were difficult to ascertain because of the high gas content. Sound velocity measurements were generally not possible because of the gas and, when obtained, showed highly variable velocities. Some good measurements were made between 724 and 1066 meters, and fell into two general ranges: one about 1.75 to $2.1 \mathrm{~km} / \mathrm{sec}$; the other, from the lower 200 meters, between 2.9 and $5.9 \mathrm{~km} / \mathrm{sec}$. Thermal conductivity data were variable, but generally showed an increase with depth. Temperature was measured at eight depths, and gave five reliable measurements. These points defined an essentially constant geothermal gradient of $35^{\circ} \mathrm{C} / \mathrm{km}$, similar to the value of $36^{\circ} \mathrm{C} / \mathrm{km}$ determined from Site 379. Heat flow at this site was $0.99 \times 10^{6} \mathrm{cal} / \mathrm{cm}^{2} \mathrm{sec}$ $( \pm 0.10)$ a value similar to that of 379 (likewise, some anomalously high temperature readings were also recorded at this site, as at 379). Some of the seismic reflectors from this site correlate with lithologic changes, particularly with the turbidites and other sedimentological discontinuities.

\section{Site 381}

Nine sedimentary units were described from Site 381 (Table 4) and, like Site 380 , terrigenous sediments tended to be prevalent in the upper part of the section, and chemical sediments common in the lower portion of the section. There is considerable evidence to suggest that several unconformities are present in the section at Site 381 . This site probably reached the oldest sediments, and we were clearly within the Miocene at the bottom of the hole. Lithified siderite layers were found at this site and at 380 , and are useful for correlation between the two areas. Unit 6 contained breccia and shellhash, which were deposited in very shallow water (see Stoffers and Müller, this volume). This unit is clearly correlative to Unit IVd from Hole 380A. The 
TABLE 3

Stratigraphic Units From Site 380

\begin{tabular}{|c|c|c|c|c|}
\hline Unit & $\begin{array}{l}\text { Thickness } \\
(\mathrm{m})\end{array}$ & $\begin{array}{l}\text { Interval } \\
(\mathrm{m})\end{array}$ & Cores & General Characteristics \\
\hline I & 332.5 & $0-332.5$ & $0-35$ & $\begin{array}{l}\text { Terrigenous sediments deposited } \\
\text { in both a marine and non-marine } \\
\text { environment; } 5 \text { subunits }\end{array}$ \\
\hline Ia & 0.30 & $0-0.30$ & - & $\begin{array}{l}\text { Nannofossil ooze known from piston } \\
\text { cores }\end{array}$ \\
\hline $\mathrm{Ib}$ & $0-2$ & $0.30-2.0$ & 1 & Sapropel \\
\hline Ic & 40 & $2-42$ & $1-5$ & $\begin{array}{l}\text { Muds and sandy silts, fresh-water } \\
\text { diatoms }\end{array}$ \\
\hline Id & 34 & $42-76$ & $5-8$ & $\begin{array}{l}\text { Diatomaceous muds, marine } \\
\text { conditions indicated by diatoms } \\
\text { and pollen suggest warm climate } \\
\text { interrupted by two cold phases }\end{array}$ \\
\hline Ie & 66.5 & $76-142.5$ & $9-15$ & $\begin{array}{l}\text { Terrigenous mud, some thin sapropel } \\
\text { horizons, mainly fresh water; climate } \\
\text { changed from warm at base to cold } \\
\text { at top }\end{array}$ \\
\hline If & 28.5 & $142.5-171$ & $16-18$ & $\begin{array}{l}\text { Diatomaceous mud and silt, diatoms } \\
\text { indicate brackism marine conditions, } \\
\text { warm climate }\end{array}$ \\
\hline Ig & 95 & $171-266$ & $19-28$ & $\begin{array}{l}\text { Mud with some fresh-water diatoms; } \\
\text { pollen indicates cold climate }\end{array}$ \\
\hline Ih & 66.5 & $266-332.5$ & $29-35$ & $\begin{array}{l}\text { Muds and turbidites; turbidites } \\
\text { correlate with those of Unit } 8 \\
\text { at Site } 379 \text {, lower part of unit } \\
\text { deposited in brackish-marine } \\
\text { pollen indicate a change from warm } \\
\text { to cold climate }\end{array}$ \\
\hline II & 114 & $332.5-446.5$ & $\begin{array}{l}380-36 \\
\text { to } \\
380 \mathrm{~A}-12\end{array}$ & $\begin{array}{l}\text { Siderite, seekreide, and muds; } \\
\text { mainly chemically deposited sedi- } \\
\text { ments; some varves that may not be } \\
\text { annual; marine influence indicated } \\
\text { in Core } 36 \text {; generally warm climate }\end{array}$ \\
\hline III & 198 & $446.5-644.5$ & $13-34$ & $\begin{array}{l}\text { Seekreide and muds, some patterns of } \\
\text { cyclic sedimentation; ostracodes } \\
\text { suggest deep fresh water }\end{array}$ \\
\hline IV & 324.5 & $644.5-969$ & $34-68$ & $\begin{array}{l}\text { Chemically deposited sediments; } \\
\text { muds and coarse clastics; } 5 \text { subunits }\end{array}$ \\
\hline IVa & 73.5 & $644.5-718$ & $34-42$ & $\begin{array}{l}\text { Siderite and diatomaceous sediments } \\
\text { numerous mangano-siderite inter- } \\
\text { calations; environment probably } \\
\text { varied from fresh to brackish water; } \\
\text { some marine influx; warm climate }\end{array}$ \\
\hline $\mathrm{IVb}$ & 132 & $718-850.3$ & $42-56$ & $\begin{array}{l}\text { Laminated seekreide diatomite, and } \\
\text { diatomaceous marls; warm climate with } \\
\text { some fluctuations, brackish at bottom } \\
\text { to fresh at top }\end{array}$ \\
\hline IVc & 14.2 & $850.3-864.5$ & $56-37$ & $\begin{array}{l}\text { Laminated aragonite and diatomaceous } \\
\text { shale, light and dark varves, some } \\
\text { slump deposits, brackish to marine } \\
\text { environments }\end{array}$ \\
\hline IVd & 19 & $864.5-883.5$ & $58-59$ & $\begin{array}{l}\text { Coarse clastic, stromatolitic dolomite } \\
\text { diatoms, etc. indicate very shallow } \\
\text { water conditions; large clasts suggesting } \\
\text { transport }\end{array}$ \\
\hline IVe & 85.5 & $883.5-969$ & $60-68$ & $\begin{array}{l}\text { Laminated seekreide marls and dolomite, } \\
\text { probably shallow varves }\end{array}$ \\
\hline V & 104.5 & $969-1073.5$ & $69-80$ & $\begin{array}{l}\text { Black shale with dolomite laminations, } \\
\text { probably a brackish marine environment; } \\
\text { warm pollen with some palm forms }\end{array}$ \\
\hline
\end{tabular}

previous comments made about the micropaleontological work also apply for this site.
The fresh-water pore fluid sequence noted at the other two sites was not present here, and salinity increased almost 
TABLE 4

Stratigraphic Units From Site 381

\begin{tabular}{|c|c|c|c|c|}
\hline Unit & $\begin{array}{l}\text { Thickness } \\
\text { (m) }\end{array}$ & $\begin{array}{l}\text { Interval } \\
\text { (m) }\end{array}$ & Cores & General Characteristics \\
\hline 1 & 171 & $0-171$ & $1-18$ & $\begin{array}{l}\text { Terrigenous mud, some turbidites, } \\
\text { some marine diatoms; pollen suggests } \\
\text { cold climate; probably some material } \\
\text { missing }\end{array}$ \\
\hline 1a & 9 & $161.5-171$ & 18 & $\begin{array}{l}\text { Terrigenous silty sand which could be } \\
\text { a beach deposit }\end{array}$ \\
\hline 2 & 2 & $171-173$ & 19 & $\begin{array}{l}\text { Seekreide - again some material may } \\
\text { be missing. }\end{array}$ \\
\hline 3 & 112 & $173-285$ & $19-31$ & $\begin{array}{l}\text { Diatomaceous sapropelic mud, fresh- } \\
\text { water diatoms, two mangano-siderite } \\
\text { layers; cold period for upper part, warm } \\
\text { below Core } 26\end{array}$ \\
\hline 4 & 38 & $285-323$ & $32-35$ & $\begin{array}{l}\text { Diatom-rich seekreide, marine diatoms; } \\
\text { pollen indicates a warm period }\end{array}$ \\
\hline 5 & $\sim 30$ & $\sim 323-352$ & $36-38$ & $\begin{array}{l}\text { Aragonite-rich diatomaceous sapropelic } \\
\text { mud, brackish diatoms, warm climate }\end{array}$ \\
\hline 6 & $\sim 85$ & $\sim 352-437$ & $39-47$ & $\begin{array}{l}\text { Pebbly mudstone, breccia, and shellhash; } \\
\text { poor recovery; shallow or supratidal } \\
\text { deposition }\end{array}$ \\
\hline 7 & $\sim 28$ & $\sim 437-465$ & $48-50$ & $\begin{array}{l}\text { Laminated, black siltstone with fresh- } \\
\text { water diatoms }\end{array}$ \\
\hline 8 & $\sim 10$ & $\sim 465-475$ & 51 & $\begin{array}{l}\text { Breccia; indications of soft sediment } \\
\text { deformation }\end{array}$ \\
\hline 9 & $\sim 30$ & $\sim 475-503$ & $52-54$ & $\begin{array}{l}\text { Siltstone, contains Engelhardia; } \\
\text { vegetation thought to be of late } \\
\text { Miocene age }\end{array}$ \\
\hline
\end{tabular}

immediately with depth. This, in part, is due to the absence of some surface layers from the section. By Core 3, the interstitial salinities were higher than the present Mediterranean levels, and by 100 meters reached $65^{\circ} / \mathrm{c2}^{\circ 0}$, but then leveled out and remained constant until about 360 meters. At this point, below some of the more densely cemented limestones and dolomites, the values started to decrease.

Water content values from this site are variable, and show variations that correlate with lithologic changes. Wet bulk densities are unusually low and have a slight tendency to increase with depth. Sound velocity measurements were restricted to some surface values, which ranged from 1.47 to $1.56 \mathrm{~km} / \mathrm{sec}$, and to some measurements made between 382 and 399 meters subbottom, which ranged from 5.95 to 6.50 $\mathrm{km} / \mathrm{sec}$. Thermal conductivity in the upper part of the section was generally low and variable, and the usual tendency for values to increase downward was not obvious. Reflectors from the seismic profiling system again showed good correlation with some of the lithologic units.

\section{GEOPHYSICAL SURVEYS}

Two seismic surveys of potential drill sites were made prior to the visit of Glomar Challenger. Malovitsky et al. (this volume), made a survey of the Site 379 area using a sparker-type system. They noted three distinct acoustical units. The upper one, with a thickness of 240 to 400 meters, had relatively thin layers with a gentle northeasterly dip. The second unit was 150 to 200 meters thick and had thicker stratification. A relatively strong reflector separated the second unit from the deeper third unit. The difference bet- ween the upper and second unit may be due to the higher incidence of turbidites in the upper unit.

A survey of portions of the Black Sea was made by French scientists (Letouzey et al., this volume) using a multichannel seismic system. Their paper includes an excellent summary of the past history of the Black Sea interpreted in light of modern concepts of sea-floor spreading. One of their objectives was to correlate seismically the different drill sites. This proved difficult with Site 381 because of a talus slope between the site and the abyssal plain, and because Letouzy et al., did not have a multichannel record in the area. Using Woods Hole Oceanographic Institution profiles, however, they were able to tie it in with their data. They studied the depth variation of RMS sound velocities (calculated from seismic data) and found no meaningful variations in velocity other than that due to sediment compaction. In comparison to abyssal plains in the Mediterranean and Atlantic, the Black Sea velocities are relatively low, probably due to the rapid sedimentation in the Black Sea that may have lead to undercompaction.

A particularly strong and continuous reflector (Reflector K) was detected in the abyssal plain area (Sites 379 and 380) and appeared just below the bottom of Hole 380A. This reflector deepens to the north under the Danube Fan area to over 2500 meters in depth. Another acoustic unit (S) detected at Site 380A appears to correlate with the top of the slump breccia sequence and has a restricted distribution apparently related to deltaic deposition.

Neprochnov (this volume) reported on the seismic and magnetic data obtained aboard Glomar Challenger. The sea 
floor area between Sites 379 and 380 is smooth and well stratified. Some very broad-scale folding is evident near the central part of the basin that may be a western extension of similar features found more to the south. The seismic sections show a general sediment thinning towards the continental slope. The profile made while going towards Site 381 also shows pinch-outs of several acoustic layers, a point consistent with the drilling results from this site.

Erickson and von Herzen examined the heat-flow data from the three sites. They believe that gas expansion in their measurements of thermal conductivity may have produced systematically low values. However, the values they observed are similar to those measured at other sites where gasses were not noticeable, thus it is possible that the effect of the interstitial gasses on thermal conductivity may be small. Their heat-flow data indicate a tendency for higher interval heat flow in the uppermost interval, with a significant decrease in the next deeper interval, with finally and gradually increasing interval heat-flow values to the bottom.

The measured heat flow at the three sites is between 0.98 and $1.18 \times 10^{6} \mathrm{cal} / \mathrm{cm}^{2} \mathrm{sec}$; this value should probably be increased to $1.6 \pm 0.2 \times 10^{6} \mathrm{cal} / \mathrm{cm}^{2} \mathrm{sec}$ to compensate for the effects of regional sedimentation and, to a lesser degree, thermal refraction. This value is consistent with other geophysical and geological data that suggest the basin to be fairly old.

\section{SHALLOW BASIN OR DEEP BASIN?}

The general geophysical framework of the Black Sea basin has been summarized by Neprochnov and Ross (this volume). The origin of the basin is controversial, as is its age; the great thickness of sediments suggests that a middle to late Mesozoic age is probable. Seismic profiles show indications of slumping of large masses of sediment from the shelf and slope regions out to the deeper parts of the basin. Shallow reflectors from the abyssal parts of the sea, which drilling has shown to be turbidites, are traceable over much of the flat-floored part of the sea.

Some authors (Stoffers et al., this volume; Schrader, this volume; Degens et al., this volume) have suggested that the entire Black Sea in the recent past was much shallower and, since about the Cromerian has subsided to its present depth. This argument in large part, is based on the good evidence of subaerial exposure and probable erosion of sediments at Site 381 (present water depth $1750.5 \mathrm{~m}$; sediment in question at about $400 \mathrm{~m}$ subbottom depth) and very shallow water conditions at Site 380 (present water depth $2115 \mathrm{~m}$, sediment in question at about $860 \mathrm{~m}$ subbottom depth). Thus a subsidence of 2000 to 3000 meters is possible. An alternative to this subsidence is that the above sediment characteristics resulted from lowered sea (lake) level in a basin having similar depths to the present one.

Two pieces of information suggest that the basin has not undergone such recent large-scale subsidence. The first is the general absence of large-scale earthquakes from the Black Sea area (see, for example, Fig. 11, Neprochnov and Ross, this volume). The second, and perhaps more important, is that numerous seismic profiles have been made across the shallow parts of the Black Sea, across the basin slope, and into deep water (see Figure 2, for example), and these profiles do not show any indication of downfaulting or recent subsidence of the scale mentioned above. This is not meant to imply that subsidence does not occur in the Black Sea (indeed, how could $17 \mathrm{~km}$ of sediments accumulate in the central area without subsidence), but that the scale suggested by these authors is not consistent with the known geophysical data. It is, however, possible that small blocks of material have been downfaulted or have slid to greater depths. This possibility may in part explain the past shallow-water conditions at Sites 380 and 381 , but based on the geophysical evidence, lowering of sea level must have the major role.

\section{SEDIMENTS}

Recent sediments of the Black Sea have been studied in considerable detail by Soviet scientists such as Trimonis and his colleagues, and by American scientists using material collected during a 1969 cruise of R/V Atlantis II into the area. The available data can be used to develop a relatively comprehensive framework of the deposition of the Recent sediments (see Ross, Stoffers, and Trimonis, this volume).

The present sediment distribution pattern in the Black Sea is a mixture of terrigenous sediments along the shelf and flanks of the basin, turbidites in the central areas, and biogenic carbonates (mainly coccolithophorids) in the deep portions of the basin. Studies from piston core samples have distinguished three distinct sedimentary units that are traceable across the Black Sea and can be explained by recent environmental changes due to rising sea level and the increase of salinity within the basin (see Ross, Stoffers, and Trimonis, this volume). The present drainage area of the Black Sea region is dominated by the Russian Platform (about $85 \%$ ) and high mountain areas (about 15\%). The rivers draining these areas carry at least $150 \times 10^{6}$ tons of sediment yearly into the Black Sea. The main input river is now the Danube, although this may not have been the case in the past. Deposition and accumulation of biogenous material has been relatively minor, except during certain periods, although the production of organic matter is estimated at over $800 \times 10^{6}$ ton per year (dry weight).

Stoffers and Müller (this volume) made an extensive study of the mineralogy and lithofacies of the Black Sea sediments obtained by DSDP drilling. They noted that three basic sediment types predominate: terrigenous, chemical (calcite, high-magnesian calcite, aragonite, dolomite, siderite), and biogenic (mainly diatomaceous). They found, as did other workers, that the terrigenous muds are more abundant in the Pleistocene or upper part of the sedimentary sequences, whereas chemical sediments are dominant in the lower Pleistocene and Pliocene sediments. In general, the biological constituents are relatively minor in abundance. As also noted by others, upper Pleistocene sedimentation was strongly influenced by changing climatic conditions related to glacial events. Source areas for the sediments are from the north (Danube), whereas the older sediments (based on the abundance of smectite) were mainly derived from the south.

Basically five different lithofacies were recognized, and can be related to changing environmental conditions in the basin. These facies are: terrigenous muds, seekreide, sapropelic diatomaceous clay, siltstone with dolostone intercalations, and siltstone. These facies are defined mainly by 




their mineralogy, color, and sedimentary structure. The columnar distribution of these facies at the three sites is shown in Figure 3.

The principal lithology of the terrigenous mud facies is a structureless dark greenish gray mud. Occasionally there are intercalations of sandy silts and sands. The coarser beds are often graded and are turbidites. This facies comprises the entire section of Hole 379A, the upper 300 meters of Hole 380 , and 170 meters of Hole 381 .

In some units, a cyclic sedimentation pattern of carbonate-free sapropelic sediments and carbonate layers was noted. Stoffers and Müller explain this as due to an 


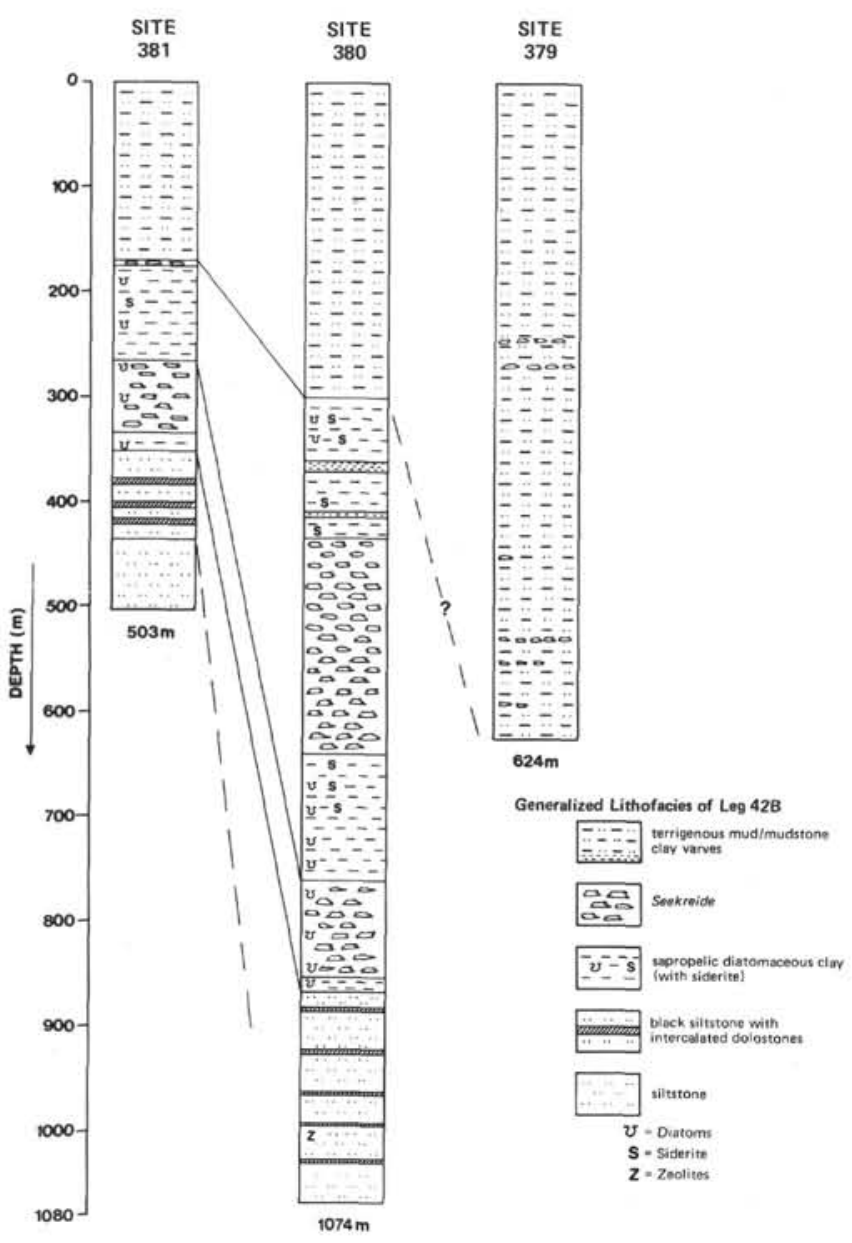

Figure 3. Columnar distribution of the five principal lithofacies from DSDP Leg 42B (from Stoffers and Müller, this volume).

oscillating density boundary, with anoxic conditions below the boundary, which lead to the dissolution of carbonates (Figure 4). The stratification may have been caused by an influx of marine waters into a relatively fresh water Black Sea. Changes in the $\mathrm{Mg} / \mathrm{Ca}$ ratio of the water would have determined the carbonate mineralogy.

The seekreide (lake chalk) is distinguished by authigenic calcite, with carbonate contents ranging from $50 \%$ to $80 \%$.

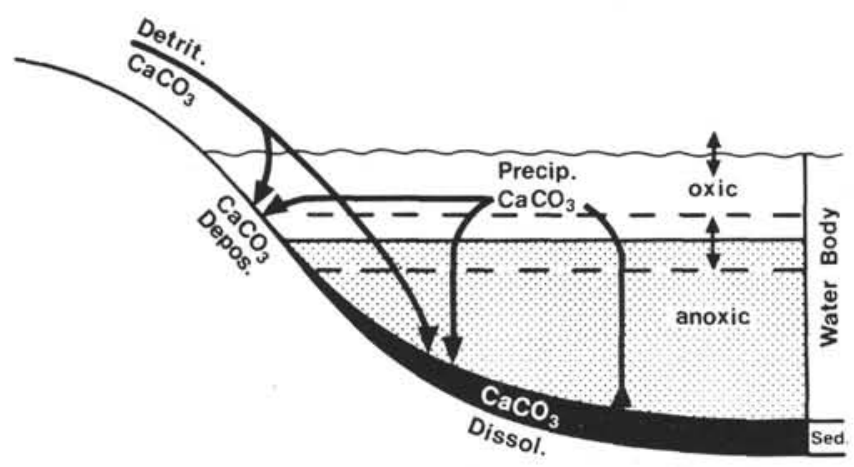

Figure 4. Schematic model for the deposition and dissolution of carbonates (from Stoffers and Müller, this volume).
The mineralogy and texture of these sediments are similar to fine-grinaed carbonate-rich sediments found in some lakes; thus the term "seekreide" is used to describe them. Seekreide generally occurs as thin beds of several centimeters thickness that are intercalated within the terrigenous muds or sapropelic clays. It is either structureless, or can have a finely laminated varved-type pattern. When structureless, it often has a rhythmic pattern of about $4 \mathrm{~cm}$ thickness, with an alternating sequence of a thin pyrite layer and a dark clay and seekreide layer with abundant burrows.

Black siltstones with intercalated dolostones were one of the more unusual lithologies found. The dolostones are laminated or massive fragments. Only brecciated sediments, including shellhash, dolomitic rock fragments (including oolitic dolostones), mud, pebbles, and sand were recovered from this facies at Site 381 . The brecciated material from this site was probably deposited in an intertidal to supratidal environment; the similar sediment from Site 380 was deposited in shallow water.

Grain-size analyses were made by Trimonis and Shimkus on sediments from all three sites, using the watermechanical method and suspensional balances. They present considerable data on grain size and sorting for the drilled sediments as well as from some Soviet piston cores. They note the generally variable grain size of the glacial and interglacial sediments, a feature common to all three sites. Usually the glacial units are enriched in sandy-silt material and turbidites as compared to interglacial units. They suggest that Pleistocene turbidite distribution is closely connected with sea-level fluctuation, and that the maximum development of turbidites corresponds to the lowest sea level (Glacial times). Turbidite deposition also occurs during high sea level times but not as often, and with limited distribution. Trimonis and Shimkus (this volume) studied the mineral composition of the coarse-silt fraction ( 0.1 to $0.05 \mathrm{~mm}$ ). They describe the mineral composition (both light and heavy mineral fractions) of the many different units and ascribe a potential source area for the sediment. In general, they found that the principal source area for sediments found at Site 379 were the Great Caucasus, with material from the southern drainage area being supplied only at certain intervals. At Sites 380 and 381 the terrigenous sediment in the Pleistocene was mainly from north and northwestern sources. Pliocene and Miocene metamorphic mineral assemblages suggest a source from the DobrudgaBosporus region. The authors feel that Danube did not exist during the Pliocene-Miocene period (or at least did not supply sediment to the Black Sea). This interesting point is similar to one made by Hsü (see Stratigraphy section).

Trimonis et al. (this volume), made X-ray mineralogical studies on the Leg 42B material. In the Recent Black Sea sediments, illite is the most common clay mineral, especially in the northern part of the basin, whereas montmorillonite is more abundant towards the south. These and other minerals reflect the two major source areas of the regionthe northern from the Russian Platform area, and the southern from the Turkish area. In the older sediments sampled by the drilling program, they noted variations in mineral content that are due to climate and sea-level variations. Clay minerals were deposited at a faster rate during glacial periods when the climate was cold and moist. There were also variations in sediment supply from the two principal 
source areas, reflecting changes in land erosion, river runoff, and sea level. Diagenetic processes (such as dolomitization and sideritization) are more important in the Pliocene and Miocene sediments than in the Pleistocene material.

Shimkus, Malovitsky, and Shumenko (this volume), describe some of the rocks they obtained by dredging the flanks of the Black Sea. Most of their samples come from rock outcrops on the Caucasian, Turkish, and Crimean slopes. Their paper shows that the range of some rocks found on land can be extended out into the Black Sea. The information they present does not bear directly on the results of the drilling project, Leg 42B; however, it does contain valuable information on older material and Black Sea stratigraphy in general. Degens et al. (this volume) made an estimate of the total sediment supply to the Black Sea using, among other things, the denudation rate in the source area. They felt that the denudation rate averages about 0.063 $\mathrm{mm} / \mathrm{yr}$, or about 100 tons $/ \mathrm{km}^{2} \mathrm{yr}$. These rates differ somewhat from those of Soviet workers (see data of Shimkus and Trimonis, table 1, in Ross, Stoffers, and Trimonis, this volume), who measured a detrital discharge of only $149 \times$ $10^{6}$ tons/yr, whereas the Degens et al. value is $229 \times 10^{6}$ tons $/ \mathrm{yr}$, or over $50 \%$ higher than the Soviet estimates. Part of this difference is due to "cosmetic" (sic) correction made in the Degens paper. If this material (higher estimate) is distributed evenly over the Black Sea, it would result in a sediment blanket of $0.4 \mathrm{~mm} / \mathrm{yr}$. Calcareous and siliceous tests would increase the value to $0.5 \mathrm{~mm} / \mathrm{yr}$. Degens et al. feel that this number is representative for steppe vegetation, but that during forest conditions the denudation rate would be reduced by about half. Correcting for compaction (correction is not given) they get an average rate of $20 \mathrm{~cm} / 1000$ $\mathrm{yr}$ for the Pleistocene. This number could be doubled in the deep basin due to slumping and turbidity current transport of sediment from shallower water.

It should be emphasized that the drainage area of the rivers that enter the Black Sea is considerable, being over $2.2 \times 10^{6} \mathrm{~km}^{2}$. At present, the Danube $\left(0.8 \times 10^{6} \mathrm{~km}^{2}\right)$, Dneper $\left(0.5 \times 10^{6} \mathrm{~km}^{2}\right)$, and Don $\left(0.4 \times 10^{6} \mathrm{~km}^{2}\right)$ drain the largest areas; the Danube carries most of the detrital load $(60 \%)$.

Degens et al. (this volume) also counted the varves in Recent sediments to make a separate check on sedimentation rates. They found as many as 270 individual bands $/ \mathrm{cm}$ of core with two bands representing one year of depositional history. Using this technique, they estimate that the upper coccolith layer (Unit 1) was deposited in 1000 years (sedimentation rate $30 \mathrm{~cm} / 1000 \mathrm{yr}$ ) and the first sapropel (Unit 2) was deposited in $4000 \mathrm{yr}$ (sedimentation $10 \mathrm{~cm} /$ $1000 \mathrm{yr}$ ). These high rates, combined with turbidity current deposition, indicate that rates as high as $1 \mathrm{~m} / 1000 \mathrm{yr}$ are possible in the deep basin. They have applied the varve technique to a few other sections where varves are present, and obtained similar results.

\section{PALEONTOLOGY}

The Black Sea cores from Leg 42B were subjected to numerous paleontologic studies; these rarely yielded any clear or relatively precise age to the sedimentary section. In rare instances, correlations with well-known paleontological events from outside the Black Sea area were possible, but more often the Black Sea fauna and floral changes were indicative of climatic or environmental effects. A combination of paleomagnetic, paleontological, and geological information is necessary for a stratigraphic evaluation of the Black Sea sediments (see next section). Below are some of the highlights of the paleontologic work.

\section{Ostracodes}

Ostracodes were studied by Oltenau (this volume) and Benson (this volume), principally from core-catcher or selected samples. Benson, in a preliminary study of ostracodes from a few selected samples (mainly from Site 380) has shown that they are mainly modern relics of late Miocene and Pliocene faunas. In general, in the 11 samples he examined, ostracodes were rare and poorly preserved. Their rare occurrence was surprising in comparison to their distribution in the present Black Sea and other similar environments. This suggested to Benson that many of the ostracode assemblages found in the upper parts of Black Sea cores may not have lived where they were found. One sample from Site 379A (Core 58, Section 4, 133-135 cm) contained a few specimens of Cyprideis littoralis (?) and Candona which suggests that the Black Sea may have been close to an alkaline-playa lake at about 200,000 B.P.

Oltenau (this volume) made a more detailed and systematic study of the Black Sea ostracodes. He noted a wide variety of forms from several stratigraphic units as well as species from several of the surrounding present or past sedimentary basins. Oltenau, however, hesitates to conclude that this indicates a mixture of older reworked elements, but rather notes that past interbasin connections could have lead to the observed mixed assemblages. He does emphasize that the principal part of the Pleistocene fauna is from the PonticCaspian Basin. He concludes that at present no stratigraphic division is possible based on the ostracode analysis.

\section{Coccoliths}

Percival (this volume) has examined over 700 samples in his study of indigenous and reworked coccoliths. Indigenous species were rare and most of the observed calcareous nannoplankton were reworked Cretaceous and Eocene to Oligocene species.

The indigenous species found by Percival were of three types:

1) An Emiliania huxleyi flora-found only at Site 379 - which is late Quaternary in age.

2) A Gephyrocapsa carribbeanica flora-found in a 100-meter-thick horizon at the top of Sites 379 and 380, which is Quaternary in age.

3) A Braarudosphaera bigelowi flora-found in thin horizons at all three sites, which ranges in age from the Jurassic to Recent.

The paleonenvironment of the Emiliania and Braarudosphaera fauna indicates brackish marine conditions, whereas the Gephyrocapsa fauna is more indicative of normal marine conditions.

The number of reworked species detected by Percival was considerable; for example, about 110 such species were found in samples from Site 379.

\section{Foraminifers}

Gheorghian (this volume) examined 339 samples from the three Black Sea sites, but only 119 were found to contain foraminifers. Based on this analysis, Gheorghian con- 
cluded that the Neogene foraminifers of the Black Sea have evolved independent of the Mediterranean since Middle Miocene time. Many of the foraminifers are eurihaline or stenohaline forms that adapted to the generally reduced salinity conditions of the Black Sea. The common benthic foraminifer species are: Ammonia beccarii, A. parkinsoniana, A. perlucida, A. tepida, A. viennensis-compacta, Elphidium advenum ponticum, E. macellum, E. reginum, and Glabratella cf. G. kartvelica.

With the exception of isolated specimens of Globigerina and Globigerinoides, planktonic foraminifers are rare. Foraminifers were also rare in the post-Glacial or Recent sediments, and are more abundant and diverse in the Glacial periods and Upper Miocene.

Gheorghian noted a Paramysis kroyeri- $P$. michaii assemblage in Cores 380A-70-76 that is Upper Sarmatian in age, and a Quinqueloculina spp. assemblage in Core 380A-77 that is a typical Sarmatian assemblage.

\section{Molluses}

Several samples of molluscs were examined by Nevesskaja (this volume) who noted that most of the species, when found, were either juvenile shells, or broken fragments of adult shells. The general paucity of these bottom-living forms is probably due to the lack of appropriate conditions for their establishment and survival. She did note that Cores 0-5 of Site 380 in the "Celia'" episode (based on the pollen and spore data) contained shells of typical Neo-Euxinian brackish water molluscs. Core 4 of the same site had a characteristic species of both upper Holocene and the Karangatian horizon. Core 36 (Site 380) in the "Anna" episode had shell remains of forms that could have Paleoeuxinian age.

\section{Pollen and Spores}

These groups were the object of rather intensive studies (Traverse, this volume; Koreneva and Kartashova, this volume). Essentially, all the samples examined contained abundant spores and pollen. Traverse devised a SteppeForest Index that could be used as a general climate indicator. The ratio was:

$$
\begin{aligned}
& \frac{\text { Artemesia }+ \text { Chenopodiaceae }+ \text { Amaranthaceae }}{\text { (the above })+ \text { Pinus + Cedrus }+ \text { Picea }+ \text { Abies }} \\
&+ \text { Quercus }+ \text { Alnus }+ \text { Ulmaceae }+(\text { other tree genera })
\end{aligned}
$$

The higher the ratio, the more it indicated cool/dry (or Steppe) conditions in the Black Sea drainage area. Likewise, the lower the number, the more it indicated warm/wet (Forest) conditions; modern Black Sea sediments have a ratio of about $10 \%$.

Traverse also made a second index, called the Marine Influence Index, which was:

$$
\frac{\text { Dinoflagellates }+ \text { Acritarchs }}{\text { Dinoflagellates }+ \text { Acritarchs }+ \text { Total Pollen }}
$$

He noted that some of the dinoflagellates can be freshwater forms. Very low values indicate non-marine environments. One especially intriguing dinoflagellate ("dinoflagellate 19-20') is plotted separately as a percentage of all dinoflagellates and acritarchs since it has a very sudden and dramatic appearance. These forms are probably brackishwater organisms that seemed to flourish when the waters became fresh. It should be mentioned that since the Black Sea spent much of its post-Miocene history as a fresh, or almost fresh-water lake, organisms such as dinoflagellates are not as common as they would be with marine conditions.

Plots of these three indexes are shown in Figure 5, and although they are based on relatively widely spaced samples (and for two of them, on a 5-point moving average), they do show rather definite and dramatic floral changes that should be due to climatic and environmental changes. Holes 380/ $380 \mathrm{~A}$ were chosen as the standard since they have more complete record, although Site 381 reaches older sediment.

Some of the results from Traverse's study are:

Site 379 probably did not reach sediments older than mid-Quaternary, or Waalian.

The very large percentage of total conifers below Hole $380 \mathrm{~A}$, Core 35 , probably reflects the pre-Glacial part of the Pleistocene.

Artemesia, which indicates colder, drier climate, is essentially absent below Hole $380 \mathrm{~A}$, Core 60 , and thus this could be interpreted as being the Pliocene-Pleistocene interface.

Possible palm pollen are found from Hole 380A, Core 71 down, and this may represent early Pliocene material.

Occurrence of Engelhardia in a few samples below Hole $380 \mathrm{~A}$, Core 70 , could be due either to reworking, or it may indicate Upper Miocene, or Lower Pliocene. In any case, it is clear that Site 381 penetrates older sediments than Site 380 .

Record for Site 381 is interrupted and probably only has two of the cold periods (Alpha and Gamma).

Presence of Tsuga below Site 381, Core 15, shows the existence of pre-Glacial Quaternary, and fits well with the general decline of Artemisia and the abundant ulmaceous pollen.

Abundant Engelhardia pollen from Site 381, Core 43 downward, indicates early Pliocene or late Miocene age. In addition, the lowest part of the section has fairly abundant palm pollen and some early Neogene forms that indicate penetration well into the Miocene.

Basically, the palynology data show that fresh- to brackish-water conditions prevailed during most of the time, with a fluctuating series of climatic conditions during the Pleistocene. At least three lengthy cold periods and four warm periods were detected (more might be detected with further detailed studies). The point emphasized by Traverse is that the transgressive periods did not necessarily coordinate with the warm periods, as may have been anticipated; in actuality, the most dramatic of such transgressive episodes occurred during "Alpha," a cold period (see Figure 5A).

Koreneva and Kartashova (this volume) were able to correlate many of their spore and pollen samples to known Black Sea stratigraphy (see Table 5). Their work, which so far has been limited to Sites 379 and 380 , notes the dramatic change from the more subtropical flora of the Pliocene to the repeated alternation of glacial vegetation (consisting of Steppe assemblages) and interglacial vegetation (consisting of Forest coenoses) in the Pleistocene. These results are summarized in Table 5B. Cores 12-32 from Hole 380A, 


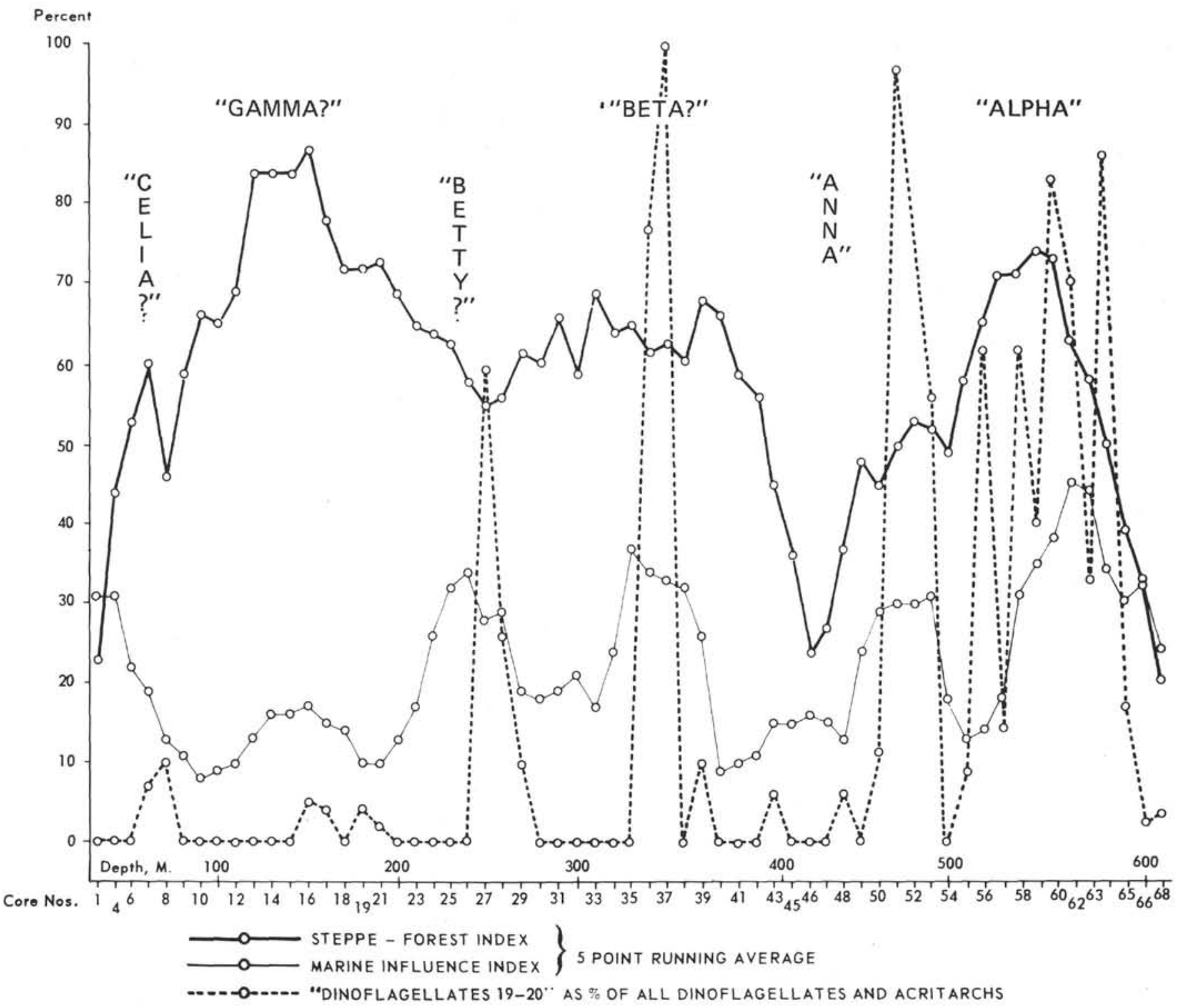

Figure 5A. Basic palynological data from Site 379. Data from core catcher samples. See text for explanation of different ratios.

according to Koreneva and Kartashova, are of Gurian (Gunz) age, whereas Cores 7-11 are of Chauda (GunzMindel) age. If this correlation is correct, it indicates that the "Alpha" Glacial period is Tiglian or Pretiglian (following the more common European Classification scheme), an older age than generally thought. The authors felt that the lower section of Hole $380 \mathrm{~A}$ (Cores 33 to 80 ) represented the Pliocene; Traverse (this volume) also put the boundary within this interval. He chose a depth below Core 60 (Hole $380 \mathrm{~A}$ ) where Artemisia (a form typical of the colder and drier Pleistocene) is absent. Further up in the section, Koreneva and Kartashova put Cores 13-15 (Hole 379A) and Cores 9-11 (Hole 380) into the Postuzunlarian or Saalian. If the age assignment is correct, the "Gamma" Glacial period is correlative with the Riss, and the "Beta" Glacial period with the Mindel or Eesterian. Traverse did not attempt any age determinations nor speculate on the ages of the different Glacial and interglacial periods.

\section{Diatoms}

Diatoms were among the most highly studied faunal group, and two important papers have resulted (Schrader, this volume, and Jouse and Mukhina, this volume). Diatoms are especially valuable to the Black Sea interpretation in that they can be most responsive to environmental variations.

The absence of diatoms below Core 29 at Site 379 was noted by all workers. It should be stressed that the two groups did not study the same samples nor have sufficient and continuous material to make the detailed study they probably wanted to do. Both groups used their own but different numbering system for the sedimentologic units; however, correlation between their data is possible by using core numbers.

Jousé and Mukhina divided the diatoms from Site 379 into four zones: 


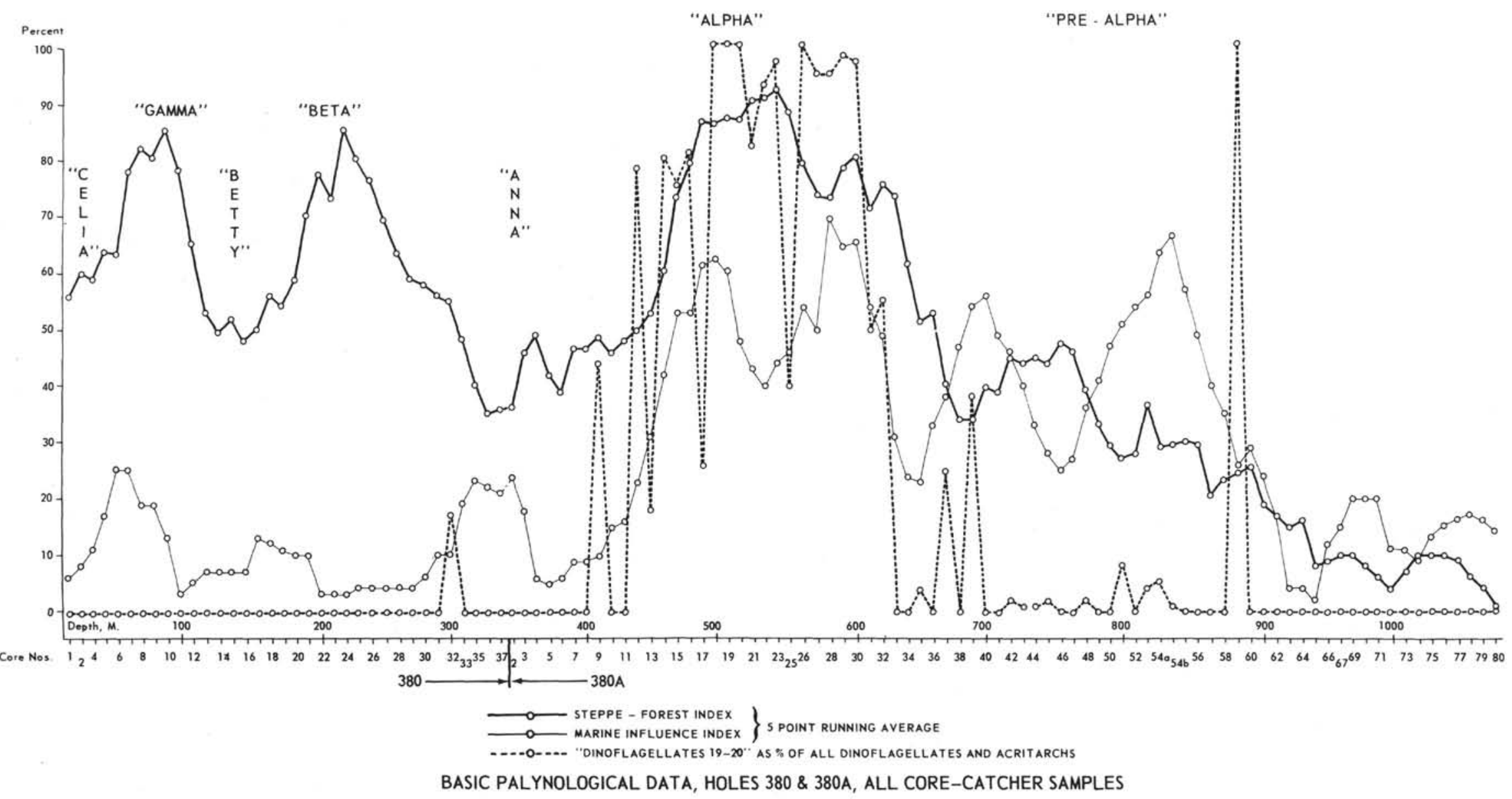

Figure 5B. Basic palynological data from Site 380. 


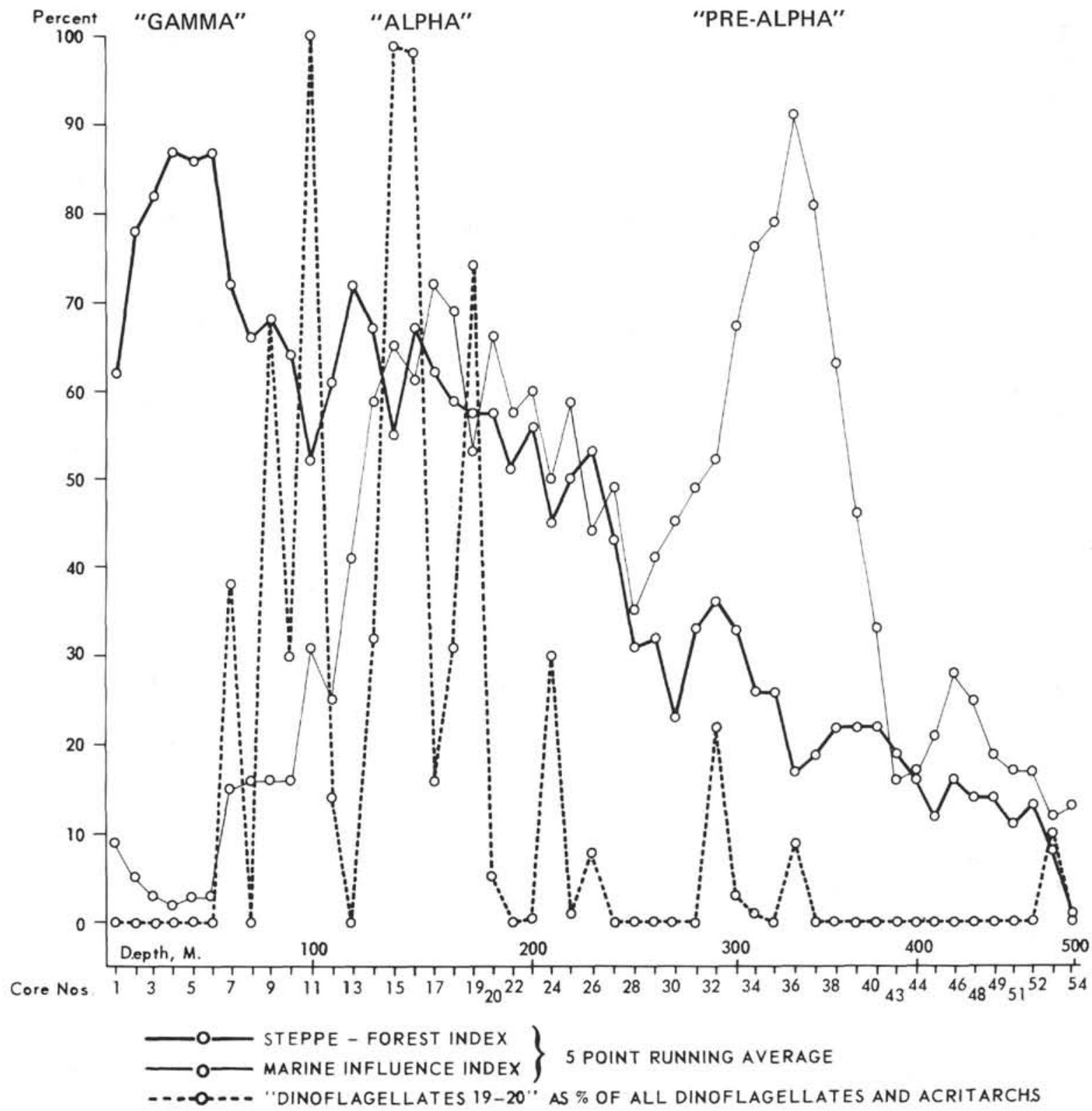

Figure 5C. Basic palynological data from Site 381.

1) Cores 7, CC to 8, CC-fresh-water assemblage with some brackish water and sporadic marine forms-relatively cold water species.

2) Cores 9.2 to $10, \mathrm{CC}$-marine, moderately warm water assemblage with no fresh-water forms.

3) Cores 17.1 to 25.1 -brackish-water and fresh-water halophile species assemblage typical of fresh-water lakes.

4) Cores 25.2 to 29.4 marine and relatively cold water assemblage.

They dated these zones as Novo-Euxinian, Karangat, Uzunlar, and Drevne-Euxinian, respectively. Schrader, on the other hand, noted basically four marine periods from Site 379. These occur in his Unit II (Cores 8-11), Univ IV (Cores 12-24), and two in Unit V(Cores 24-29). Considering sampling differences, Schrader and Jousé and Mukhina have similar conclusions on the environmental conditions at Hole 379A.
For Site 380, Schrader described nine units, with three marine episodes in Hole 380 (also three small excursions), and three also in 380A (the upper two of which are similar to the lower two of 380). Correlations between the two holes are

Hole $380 \mathrm{~A}$, Core 1 to Hole 380 , Core 36

Hole $380 \mathrm{~A}$, Core 3 to Hole 380 , Core 39

and seem to be generally similar to those of other studies. Schrader's marine episodes coincide with Traverse's warm water ratios; however, Traverse and Schrader do not agree on their correlations between Sites 379 and 380 (see below).

Jousé and Mukhina describe three major marine phases from Site 380 that are essentially the same as those noted by Schrader. Jousé and Mukhina place the Pliocene at the base of Core 31, Hole 380A, and the start of the Pontian at Core 55 , Section 3, Hole 380A. They distinguished six major diatom assemblages from this site. 
TABLE 5A

Palynological Correlation Between the Three B lack Sea Sites as Determined by Ratios of Spores and Pollen (see text from Traverse, this volume)

\begin{tabular}{llll}
\hline $\begin{array}{l}\text { Steppe-Forest } \\
\text { Index }\end{array}$ & $\begin{array}{c}\text { Position in } \\
\text { Site 379 }\end{array}$ & $\begin{array}{c}\text { Position in } \\
\text { Site 380 }\end{array}$ & $\begin{array}{c}\text { Position in } \\
\text { Site 381 }\end{array}$ \\
\hline $\begin{array}{l}\text { Celia } \\
\text { (Forest) }\end{array}$ & Cores 1-9 & Cores 1-6 (380) & Missing \\
$\begin{array}{l}\text { Gamma } \\
\text { (Steppe) }\end{array}$ & Cores 10-21 & Cores 7-12 & Cores 1-6 \\
$\begin{array}{l}\text { Betty } \\
\text { (Forest) }\end{array}$ & Cores 24-34 (?) & Cores 13-20 & Cores 7-10(?) \\
$\begin{array}{l}\text { Beta } \\
\text { (Steppe) }\end{array}$ & Cores 35-41 (?) & Cores 21-28 & $\begin{array}{l}\text { Probably } \\
\text { missing }\end{array}$ \\
$\begin{array}{l}\text { Anna } \\
\text { (Forest) }\end{array}$ & Cores 42-55 & Cores 1-13 (380A) & $\begin{array}{l}\text { Probably } \\
\text { missing }\end{array}$ \\
$\begin{array}{l}\text { Alpha } \\
\text { (Steppe) }\end{array}$ & Cores 53-61 & Cores 14-35 & $\begin{array}{l}\text { Cores 11-27 } \\
\text { Pre-Alpha }\end{array}$ \\
$\begin{array}{l}\text { Cores 62-68 (?) } \\
\text { a Cores 36-80 }\end{array}$ & Core 28-(?) \\
\hline $\begin{array}{l}\text { Based oxtrapolation from data presented in Site Reports - cor- } \\
\text { than occurrence of key species, and thus could }\end{array}$
\end{tabular}

TABLE 5B

Pollen and Spore Stratigraphy, as Determined by Koreneva and Kartashova (this volume)

\begin{tabular}{|c|c|c|c|c|c|}
\hline Black Sea Age & $\begin{array}{c}\text { Cores } \\
\text { Hole } 379\end{array}$ & $\begin{array}{c}\text { Cores } \\
\text { Hole } 380\end{array}$ & $\begin{array}{l}\text { Cores } \\
\text { Hole } 380 \mathrm{~A}\end{array}$ & $\begin{array}{l}\text { Alpine } \\
\text { Age } \alpha\end{array}$ & Remarks \\
\hline Old Black Sea & - & - & - & - & $\begin{array}{l}\text { Formed during Black Sea } \\
\text { regression }\end{array}$ \\
\hline New Euxinian & top & top & - & & $\begin{array}{l}\text { Temperate, cool predominance } \\
\text { of glass pollen }\end{array}$ \\
\hline Surozhskie & - & 2 & - & Würm & $\begin{array}{l}\text { Poorly characterized - warm- } \\
\text { ing and moistening of climate }\end{array}$ \\
\hline Post-Karangatien & $4-10.5$ & $3-6(?)$ & - & & $\begin{array}{l}\text { Alternation of climate, upper } \\
\text { part equal to glacial maximum }\end{array}$ \\
\hline Karangatien & $10.6-12.1$ & 7 & - & Riss-Würm & Temperate warm fauna \\
\hline Postuzunlarien & $13-15$ & $9-11$ & - & & Cold \\
\hline Uzunlarien & $16-20$ & $11-19(?)$ & - & Riss & $\begin{array}{l}\text { Poorly preserved pollen, } \\
\text { temperate warm }\end{array}$ \\
\hline $\begin{array}{l}\text { Drevne-Euxinian } \\
\text { (late) }\end{array}$ & $21-42$ & $19(?)-32$ & - & & Temperate cold flora \\
\hline $\begin{array}{l}\text { Paleouzunlarien- } \\
\text { Drevne-Euxinian } \\
\text { (early) }\end{array}$ & $43-54$ & $33-37$ & - & $\begin{array}{l}\text { Mindel- } \\
\text { Riss }\end{array}$ & Temperate warm flora \\
\hline Regressive layers & $55-66$ & $38-40$ & $2-7$ & Mindel & Temperate cold \\
\hline Chauda & $67-68$ & - & $7-11$ & $\begin{array}{l}\text { Gunz- } \\
\text { Mindel }\end{array}$ & $\begin{array}{l}\text { Temperate with some sub- } \\
\text { tropical }\end{array}$ \\
\hline Gurian & - & - & $12-32$ & Gunz & $\begin{array}{l}\text { Poor preservation, probably } \\
\text { from cold epoch of early } \\
\text { Pleisotcene }\end{array}$ \\
\hline Pliocene & - & - & $33-80$ & Pliocene & $\begin{array}{l}\text { Rich diverse fauna temperate- } \\
\text { warm subtropical fauna }\end{array}$ \\
\hline
\end{tabular}

${ }^{\mathrm{a}}$ The alpine ages given in this table differ from most European classifications (see Table $8 \mathrm{~A}$ and $8 \mathrm{~B}$ for comparison).

At Site 381, Schrader defined nine diatom units and two marine phases (near the surface and in Cores 35-38). Jousé and Mukhina noted the latter phase and divided the site into three diatom units.
Both authors attempted correlations between the sites based on this diatom data. Schrader established 18 correlations, based principally on species variations due to environmental changes (Table 6). Correlations 5-11 and 13-14 
TABLE 6

Stratigraphic Correlations Between Sites Based Primarily on First or Last Occurrences of Diatom Species (adapted from Schrader, this volume)

\begin{tabular}{|c|c|c|c|c|}
\hline Correlation & Hole $379 \mathrm{~A}$ & Hole 380 & Hole $380 \mathrm{~A}$ & Hole 381 \\
\hline $\begin{array}{l}\text { Abundance peak of Stephanodiscus astraea } \\
\text { (correlates with Unit } 2 \text { from piston } \\
\text { cores - see Table 3) }\end{array}$ & - & 1 & - & - \\
\hline Abrupt decrease in $S$. hantzschii & 4 & 4 & - & - \\
\hline Increase in abundance of $S$. hantzschii & 9 & 8 & - & - \\
\hline $\begin{array}{l}\text { Peak abundance of Cyclotella caspia, } \\
\text { associated with Thalassiosira marine } \\
\text { species, Chaetoceros species and absence } \\
\text { of Hermesinum adriaticum }\end{array}$ & 11 & $10(?)$ & - & - \\
\hline $\begin{array}{l}\text { Decrease in abundance of } S \text {. astraea and } \\
\quad \text { varieties and } S \text {. robustus }\end{array}$ & 16 & 15 & - & - \\
\hline $\begin{array}{l}\text { Abundance peak of } S \text {. astraea and varieties } \\
\text { and } S \text {. robustus, and one abund ance peak } \\
\text { of Actinocyclus normannii and Cyclotella } \\
\text { caspia }\end{array}$ & $\begin{array}{c}18 \\
\text { (tentative) }\end{array}$ & 23 & - & - \\
\hline Abundance peak of $S$. astraea and $S$. robustus & $\begin{array}{c}22 \\
\text { (top) }\end{array}$ & 31 & - & - \\
\hline $\begin{array}{l}\text { Last abundant occurrence of } A \text {. normannii } \\
\text { associated with Hermesinum adriaticum }\end{array}$ & 24 & 35 & - & - \\
\hline $\begin{array}{l}\text { First abundant occurrence of } A \text {. normannii } \\
\quad \text { associated with } H \text {. adriaticum }\end{array}$ & 25 & 36 & 1 & $\begin{array}{c}1 \\
\text { (Section 3) }\end{array}$ \\
\hline $\begin{array}{l}\text { Decrease in abundance of } A \text {. normannii, in- } \\
\text { creased } S \text {. astraea and its varieties }\end{array}$ & 29 & 39 & 3 & 3 \\
\hline $\begin{array}{l}\text { Abundance peak of } A \text {. normannii and no } \\
\text { H. adriaticum }\end{array}$ & 29 & 39 & $3(?)$ & - \\
\hline $\begin{array}{l}\text { Last occurrence of freshwater diatoms in } \\
\text { lower Black Sea section }\end{array}$ & - & - & $\begin{array}{l}32 \\
\text { (or } 34)\end{array}$ & 19 \\
\hline $\begin{array}{l}\text { Abundance peak within the range of } \\
\text { Melosira granulata var. angustissima } \mathrm{f} \text {. } \\
\text { curvata, and occurrence of } S \text {. omarensis } \\
\text { and } S . \text { Cyclotella }\end{array}$ & - & - & 38 & 22 \\
\hline $\begin{array}{l}\text { Last common occurrence of } S \text {. carconensis } \\
\quad \text { (triangulate type) }\end{array}$ & - & - & 40 & 26 \\
\hline $\begin{array}{l}\text { First common occurrence of } S \text {. carcoensis } \\
\quad \text { (triangulate type) }\end{array}$ & - & - & 42 & $\begin{array}{c}28 \\
\text { (middle } \\
\text { part) }\end{array}$ \\
\hline $\begin{array}{l}\text { Last common occurrence of } S \text {. binderianus } \\
\text { type a. Thalassiosira aff. lineata }\end{array}$ & - & - & 44 & 30 \\
\hline $\begin{array}{l}\text { First common occurrence of S. binderianus } \\
\text { type a, also the range of Coscinodiscus(?) } \\
\text { stokesianus in Hole } 380 \mathrm{~A} \text { (Cores } 54 \text { to } 51 \text { ) } \\
\text { and in Hole } 381 \text { (Cores } 34-32 \text { ), the range } \\
\text { of Cyclotella operculata. }\end{array}$ & - & - & 47 & $\begin{array}{c}32 \\
\text { (bottom) }\end{array}$ \\
\hline $\begin{array}{l}\text { Last common occurrence of Actinocyclus } \\
\text { ehrenbergii, slightly below common oc- } \\
\text { currence of Synedra indica }\end{array}$ & - & - & $\begin{array}{c}55 \\
\text { (top) }\end{array}$ & $\begin{array}{c}35 \\
\text { (top) }\end{array}$ \\
\hline
\end{tabular}

do not fit with Traverse's correlations based on spore and pollen data (Figures 5A, B, and C). Jousé and Mukhina's correlations (Table 7) are based on their eight diatom units (see below). They assigned dates to these units, using various paleontological and sedimentological criteria. Schrader also assigned ages to the sediments, but he principally used estimated sedimentation rates. He felt that the present fresh-water diatom stratigraphy was not adequate for dating. It is difficult to compare the stratigraphy of the two studies because of differences in nomenclature, i.e., the Waalian or Danube/Ginz can be correlative with the Chauda in one classification (Table 8A) and with the Gurian in another (Table $8 \mathrm{~B}$ ); there are also considerable differences in the stratigraphy of Jouse' and Mukhina (Table 7) and Koreneva and Kartashova (Table 5B).

Jousé and Mukhina's stratigraphy can be synthesized into eight major units:

Unit I-Holocene, with marine diatoms similar to present-day Black Sea flora.

Unit II-Deficient in diatoms. Diatoms, when found, are fresh-water forms (Stephanodiscus astraea was most frequent). 
TABLE 7

Correlations, Ages, and Biostratigraphy of Black Sea Sites (adapted from Jousé and Mukhina, this volume)

\begin{tabular}{|c|c|c|c|}
\hline Unit & Cores & Age & Comments \\
\hline I & Piston Cores & Holocene & Marine diatoms \\
\hline II & $\begin{array}{l}379 \mathrm{~A}-1.4-6, \mathrm{CC} \\
380-0, \mathrm{CC}-5.3\end{array}$ & Novo-Euxinian & Deficient in diatoms \\
\hline III & $\begin{array}{l}379 \text { A-7, CC-11.3 } \\
380-5.3-11, \text { CC }\end{array}$ & Karangat & $\begin{array}{l}\text { Marine diatoms at } \\
\text { bottom of section, } \\
\text { becoming fresh } \\
\text { towards top }\end{array}$ \\
\hline IV & $\begin{array}{l}379 \mathrm{~A}-11.3-25.1 \\
380-11-33, \mathrm{CC}\end{array}$ & $\begin{array}{l}\text { Uzunlar and } \\
\text { Paleouzunlar }\end{array}$ & $\begin{array}{l}\text { Mainly fresh-water } \\
\text { forms with some } \\
\text { brackish- and fresh- } \\
\text { water species; } \\
\text { changing climate } \\
\text { conditions }\end{array}$ \\
\hline V & $\begin{array}{l}379 \mathrm{~A}-25.1-30.2 \\
380-33, \mathrm{CC} \\
380 \mathrm{~A}-1.1-3.4 \\
381-1.2-4, \mathrm{CC}\end{array}$ & $\begin{array}{l}\text { Drevne- } \\
\text { Euxinian }\end{array}$ & $\begin{array}{l}\text { Mostly marine } \\
\text { species }\end{array}$ \\
\hline VI & $\begin{array}{l}379 \mathrm{~A}-30.2 ? \\
380 \mathrm{~A}-3.4-31, \mathrm{CC} \\
? 381-4, \mathrm{CC}-19.5\end{array}$ & Chauda & $\begin{array}{l}\text { Mainly terrigenous } \\
\text { with no diatoms }\end{array}$ \\
\hline VII A & $\begin{array}{l}380 \mathrm{~A}-31, \mathrm{CC}-40.4 \\
381-19.5-26.3\end{array}$ & Pliocene & $\begin{array}{l}\text { Fresh-water dia- } \\
\text { toms; lake condi- } \\
\text { tions; four diatom } \\
\text { zones are noted }\end{array}$ \\
\hline VII B & $\begin{array}{l}380 \mathrm{~A}-40.4-45, \mathrm{CC} \\
381-26.3-28.6\end{array}$ & & \\
\hline VII C & $\begin{array}{l}380 \mathrm{~A}-45, \mathrm{CC}-50.1 \\
381-28.6-32.2\end{array}$ & & \\
\hline VII D & $\begin{array}{l}380 \mathrm{~A}-50.1-54.1 \\
381-32.2-34.5\end{array}$ & & \\
\hline VIII & $\begin{array}{l}380 \mathrm{~A}-54.1 \\
381-34.5\end{array}$ & $\begin{array}{l}\text { Pontian } \\
\text { (Messinian) }\end{array}$ & Marine \\
\hline
\end{tabular}

Site 379A

Site 380

Cores $6, \mathrm{CC}$ to 1.4

Cores 5,3 to $0, \mathrm{CC}$

Unit III-Marine flora (Site 379A, Cores 10,CC to 9.3 becomes fresh water by $7, \mathrm{CC})$. Correlates with Karangat interglacial epoch (or Eemian of western Europe or Mikulino of USSR (Riss-Würm).

Unit IV-Mainly fresh-water diatoms, with some brackish water and marine species. Unit is thick. Site 379A, Cores 25.1 to 11, CC. Site 380 , Cores $33, \mathrm{CC}$ to 12.1 . Unit has four distinct layers. They believe that during the deposition of Unit IV the climatic conditions frequently changed with the warm stages characterized by a high diatom productivity, and low during cooler stages. Unit IV combines Paleouzunlar and Uzunlar sediments.

Unit $\mathrm{V}$-This unit is present at all sites.

$\begin{array}{lr}379 & 30.2 \text { to } 25.2 \\ 380 & 39.6 \text { to } 35.1 \\ 380 \mathrm{~A} & 3.4 \text { to } 1.1 \\ 381 & 4, \mathrm{CC} \text { to } 1.2\end{array}$

Most of the diatoms are marine, but some brackish- and fresh-water forms are present. A cold water form (Coscinodiscus normannii) is very abundant. This unit, accord- ing to Russian correlation scheme, correlates with the Drevne-Euxinian.

Unit VI-Above the Pliocene-Pleistocene boundary, it is a thick, terrigenous sequence at all sites that is barren of diatoms except for a small section at Hole $380 \mathrm{~A}$ (Core 17.2 to 17.1). The unit is of early Pleistocene age. They believe there is a major environmental change at the end of the lacustrine period that marked the end of the Pliocene, and that the decrease in temperature and increase in salinity, etc., explains the absence of diatoms.

Unit VII-A sedimentary sequence of lacustrine origin characterized by fresh-water diatoms. Depth of 200 meters at Hole 380A (Cores 54-32) and 140 meters at Site 381 (Cores 34.3-20.1). Deposition occurred in late Pliocene when Black Sea was totally isolated, and a lake. Diatoms flourished during this period. Flora, however, is unique and not similar to other lakes of this time.

Unit VIII-Oldest layer of marine origin at base of diatom-bearing layers.
Hole $380 \mathrm{~A}$
(Cores 56 to 55 )
Site 381
(Cores 34.6 to 38.1 )

They consider Unit VIII as Pontic (based on stratigraphic scheme adopted at Bratislava in 1975. The Pontic stage 
TABLE $8 \mathrm{~A}$

Pleistocene Correlation of European, North American, and Black Sea Areas (from Ross, this volume)

\begin{tabular}{|c|c|c|c|c|}
\hline Northern Europe & $\begin{array}{c}\text { Central } \\
\text { Alpine Europe }\end{array}$ & North America & Black Sea & \\
\hline Post Glacial & & & $\begin{array}{l}\text { New Black Sea } \\
\text { Old Black Sea } \\
\text { (See Table 2) }\end{array}$ & $\begin{array}{l}\text { Holocene } \\
\text { P }\end{array}$ \\
\hline $\begin{array}{l}\text { Weichselian } \\
\text { (Glacial) }\end{array}$ & Würm & & $\begin{array}{l}\text { New Euxinian } \\
\text { (Novo-Euxinian) }\end{array}$ & $\mathrm{L}$ \\
\hline $\begin{array}{l}\text { Eemian } \\
\text { (Interglacial) }\end{array}$ & Riss/Würm & Wisconsin & Karangat & $\mathrm{E}$ \\
\hline $\begin{array}{l}\text { Saalian } \\
\text { (Glacial) }\end{array}$ & Riss & & Post Uzunlar ${ }^{\mathrm{a}}$ & I \\
\hline $\begin{array}{l}\text { Holsteinian } \\
\text { (Interglacial) }\end{array}$ & $\begin{array}{l}\text { Mindel/Riss } \\
\text { (Interglacial) }\end{array}$ & Sangamonian & Uzunlar $^{\mathrm{a}}$ & S \\
\hline $\begin{array}{l}\text { Elsterian } \\
\text { (Glacial) }\end{array}$ & Mindel & Illinoian & Old Euxinian $^{\mathrm{a}}$ & $\mathrm{T}$ \\
\hline $\begin{array}{l}\text { Cromerian } \\
\text { (Interglacial) }\end{array}$ & $\begin{array}{l}\text { Gunz/Mindel } \\
\text { (Interglacial) }\end{array}$ & Yarmouthian & Post Chauda ${ }^{a b}$ & $\mathrm{O}$ \\
\hline $\begin{array}{r}\text { Menapian } \\
\text { (Glacial) }\end{array}$ & Gunz & Kansan & & $\mathrm{C}$ \\
\hline Waalian & $\begin{array}{c}\text { Danube/Gunz } \\
\text { (Interglacial }\end{array}$ & Aftonian & Chauda $^{b}$ & $\mathrm{E}$ \\
\hline Eburonian & Danube & Nebraskan & & \\
\hline Tiglian & $\begin{array}{r}\text { Biber/Danube } \\
\text { (Interglacial) }\end{array}$ & & Gurian & $\mathrm{N}$ \\
\hline Pretiglian & Biber & & Ak cagyl & E \\
\hline \multicolumn{5}{|c|}{ (Adapted from van Eysinga. 1975; and other works.) } \\
\hline
\end{tabular}

corresponds to the close of the late Miocene (Messinian stage) - early Pliocene). Some layers may be of the Meotis.

Schrader established paleosalinities for the Black Sea cores based on salinity tolerances of certain diatom species (i.e., data apply to surface and near-surface conditions). Site 380 was used as a standard and he was able to define 10 paleosalinity units (see Figure 6). According to his data, the Black Sea underwent considerable freshening at the end of the Pliocene, and became only moderately salty $(>5 \%)$ five times in the Pleistocene. Surface salinities, based on diatom data, did not exceed $40 \%$. A deepening of the Black Sea is suggested at Hole $380 \mathrm{~A}$, Core 58, and Hole 381 , Core 37, that could be synchronous with the end of the Messinian in the Mediterranean.

The salinities determined from the diatom studies were not compatible with interstitial water salinities (as determined by Manheim, this volume-see also later section). In some instances, the diatoms indicate fresh water, whereas the pore waters indicate fairly high salinities, and no explanation is obvious. The top three marine episodes at Hole
379A postulated by Calvert and Batchelor (this volume) based on locations of organic-rich material, are also reflected in the diatom data.

Schrader is of the opinion that no suitable fresh-water diatom biostratigraphy is available; thus their use for dating is strongly restricted. He has, however, attempted to date units by using estimates of sedimentation rates (see Figure 6).

Schrader, this volume, has attempted an environmental reconstruction of the Black Sea, based on his data. He feels that in the late Miocene the basin was shallow, and has subsequently subsided to its present depth. The first strong cooling phase occurred about $2.6 \times 10^{6}$ years ago and resulted in the basin becoming a fresh-water lake that underwent evaporation phases. Cold periods occurred in the Pretiglian, Tiglian, Eburonian, Waalian, and Cromerian. From $2.6 \times 10^{6}$ to $0.75 \times 10^{6}$ years the basin was dominated by sediments of chemical origin. At the end of the Cromerian, the Black Sea was isolated and started becoming a freshwater lake, becoming marine again during the Holsteinian. 
TABLE $8 \mathrm{~B}$

Pleistocene Correlation of the Black Sea With That of European Division

(from Koreneva and Kartashova, this volume)

\begin{tabular}{|c|c|c|c|c|c|c|c|}
\hline \multirow{2}{*}{ 永 } & \multirow{2}{*}{ 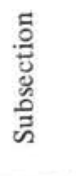 } & \multirow{2}{*}{  } & \multirow{2}{*}{$\begin{array}{c}\text { Alpinian } \\
\text { Stratigraphic } \\
\text { Scale }\end{array}$} & \multirow[b]{2}{*}{$\begin{array}{c}\text { Mediterranean } \\
\text { Sea }\end{array}$} & \multicolumn{3}{|c|}{$\begin{array}{l}\text { Subdivision of the } \\
\text { Pleistocene in USSR }\end{array}$} \\
\hline & & & & & $\begin{array}{l}\text { European Part } \\
\text { of the USSR }\end{array}$ & Black & Sea \\
\hline \multirow{9}{*}{ 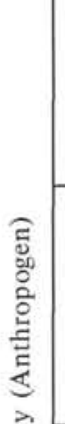 } & \multirow{4}{*}{ 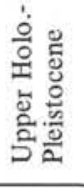 } & $7-8$ & & Flandrian & Holocene & $\begin{array}{c}\text { Black } \\
\text { Sea }\end{array}$ & $\frac{\text { Late }}{\text { Early }}$ \\
\hline & & 23 & \multirow{3}{*}{ Würm } & \multirow{3}{*}{$\begin{array}{c}\text { Grimaldian } \\
\text { (Regression) }\end{array}$} & Ostashkian & \multicolumn{2}{|c|}{ Novo-Euxinian } \\
\hline & & 45 & & & Mologo-Schexnian & \multirow{2}{*}{\multicolumn{2}{|c|}{$\begin{array}{c}\text { Surozh(?) } \\
\text { Post-Karancat }\end{array}$}} \\
\hline & & 65 & & & Kalinian & & \\
\hline & \multirow{5}{*}{ 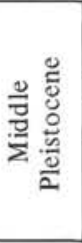 } & $90-110$ & $\begin{array}{l}\text { Riss- } \\
\text { Würm }\end{array}$ & $\begin{array}{c}\text { Neo- } \\
\text { Tirrhenian }\end{array}$ & Miculian & \multicolumn{2}{|c|}{ Karangat } \\
\hline & & & \multirow{4}{*}{ Riss } & Regression & Moskovian & \multicolumn{2}{|c|}{ Regression } \\
\hline & & & & & Odintsovian & \multicolumn{2}{|c|}{ Uzunlar } \\
\hline & & \multirow[b]{2}{*}{230} & & \multirow[t]{2}{*}{ Regression(?) } & \multirow[t]{2}{*}{ Dneprian } & \multicolumn{2}{|c|}{$\begin{array}{l}\text { Late Drevne- } \\
\text { Euxinian }\end{array}$} \\
\hline & & & & & & Regre: & ssion \\
\hline \multirow{5}{*}{ 矛 } & \multirow{5}{*}{ 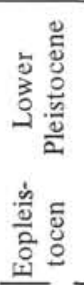 } & 300 & $\begin{array}{l}\text { Mindel- } \\
\text { Riss }\end{array}$ & $\begin{array}{c}\text { Paleo- } \\
\text { Tyrrhenian }\end{array}$ & Likhvinian & $\begin{array}{r}\text { Paleouz } \\
\text { Early Drevn }\end{array}$ & $\begin{array}{l}\text { zunlar } \\
\text { e-Euxinian }\end{array}$ \\
\hline & & & Mindel & Regression & Okan & Regres & ssion \\
\hline & & 700 & $\begin{array}{l}\text { Gunz- } \\
\text { Mindel }\end{array}$ & Sicilian & \multirow{3}{*}{$\begin{array}{l}\text { Belavezhskian } \\
\text { Stages }\end{array}$} & \multicolumn{2}{|c|}{ Chauda } \\
\hline & & & Gunz & Emilian & & \multirow{2}{*}{\multicolumn{2}{|c|}{ Gurian }} \\
\hline & & & $\begin{array}{l}\text { Danou-Gunz } \\
\text { Danau }\end{array}$ & Calabrian & & & \\
\hline
\end{tabular}

Generally fresh-water conditions returned during the Saalian and Weichselian, interrupted by marine conditions during the Eemian.

\section{STRATIGRAPHY}

As previously mentioned, probably the most difficult aspect of the Black Sea drilling results has been the establishment of a uniform and consistent stratigraphy for the units sampled. Among the reasons for this difficulty are the relative absence of definitive paleontological age markers and the general lack of agreement between workers on correlation and zonation of the sedimentary units (see Ross, this volume). A basic difference also exists between the stratigraphic interpretations made by those who described Sites 379 and 381 (Stoffers and Degens) and Site 380 (Hsï). These differences are discussed further in following paragraphs.

The stratigraphic problems are compounded because some authors use Alpine classification schemes, others Soviet classifications based on Black Sea or other surrounding areas, and still others devised new classifications or modified existing ones. In some instances workers renumbered or reorganized the original shipboard sedimentary jesignations. Table 8 shows Pleistocene correlations that are more consistent with European nomenclature $(8 \mathrm{~A})$ or with Soviet nomenclature (Table 8B, from Koreneva and Kartashova, this volume).

Hsü (this volume) and Stoffers, Degens, and Trimonis (this volume) have presented their interpretations in separate papers. Their results are summarized below. For further elucidation the interested (and careful) reader should go back to the Site Reports, to appropriate sections of the paleontology papers, and to the introductory paper of this volume, on Black Sea Stratigraphy.

The Stoffers, Degens, and Trimonis stratigraphy is based essentially on estimates of sedimentation rates, noting sediment similarities of the deeper drilled units to the cored surficial sediments (Units 1, 2, and 3) that have been dated $\left(\mathrm{C}^{14}\right)$ and studied in considerable detail (Degens and Ross, 1974). The authors also use the pollen and spore data and other information to establish cold or warm periods, etc. These interpretations (Table 9) are then tied into the European Alpine classification (an attempt is also made to correlate with a Soviet classification).

Stoffers et al. have identified a total of 16 distinct lithological units that they have correlated among the sites (Figure 7). They suggest that the chemical facies were deposited during upper Miocene to Cromerian time, and that it was during the major European glacial periods-Elsterian, Saalien, and Weichselian-when most of the terrigenous sediments were deposited. In the interglacial periodsHolsteinian, Eemian, and Holocene-there were brief marine invasions as indicated by nannofossil ooze, sapropels, and micritic intercalations. They believe that the chemical deposits were formed initially in a restrictive marine environment during the upper Miocene-Pliocene; this eventually changed to a fresh-water environment. It was during the Cromerian that the Black Sea started to deepen, a condition they feel is still occurring. This point is discussed in an earlier section of this paper where it is found to be at odds with known geophysical information.

Several additional points of the Stoffers et al. paper are important. Unit 9 was not found at Sites 380 and 381 (parts of 7 and 8 may also be missing from these sites), indicating 


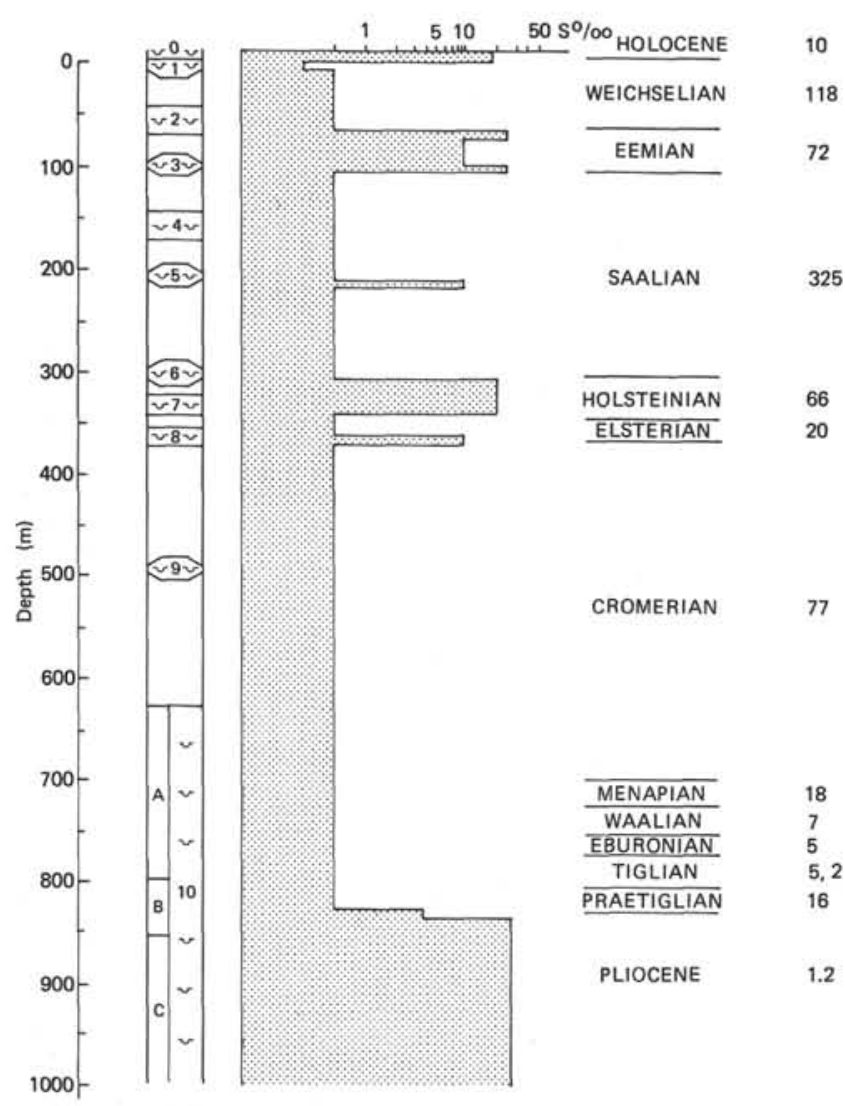

Figure 6. A generalized interpretation at Site 380 of environmental conditions at diatomaceous intervals and intermediate units in \% salinity correlated with glacialinterglacial periods (based on sedimentation rates). From Schrader, this volume.

a significant unconformity. Schrader (this volume) does not find such an unconformity at Site 380 , and believes that sedimentation was continuous there. Stoffers et al. estimate a gap of $1.5 \times 10^{6}$ years at Site 381 , and $0.5 \times 10^{6}$ years at Site 380 , and believe these gaps may represent a hypersaline episode. They suggest that this episode may be analogous to the Messinian salinity crisis of the Mediterranean, but that in the Black Sea it was more similar to the Great Salt Lake type of evaporation, and occurred in the Pleistocene.

Hsü has written two papers relative to Black Sea stratigraphy, one "Correlation of Black Sea Sequences," (called A here) and one "Stratigraphy of the Lacustrine Sedimentation in the Black Sea"' (called B here). His method of correlation is similar to the Stoffers et al. approach, in that both use whatever biostratigraphic data are available. Hsü (this volume, A), however, puts considerably more stress on this information, and does not estimate sedimentation rates based on similarities of sedimentary units. Thus he does not assign any age to the glacial and interglacial periods. He (this volume, B) also puts more emphasis on regional geological events and their effect on the Black Sea Basin. Hsü correlations (Figure 8) and those of Stoffers et al. were discussed at a post-cruise meeting (summer 1976) that resulted in considerable (but not complete) agreement on the correlation between the sites (Table 10).

The authors also differ in the general interpretation of sedimentation in the Black Sea. Hsü (this volume, B) feels that the history of sedimentation in the Black Sea can be divided into three principal zones. First is a black shale sequence (that correlates with his Unit V from Site 380) that was deposited during late Miocene (Tortonian) time. This is overlain by a zone of chemical sedimentation that extended from the late Miocene (Messinian) to early Quaternary time. Terrigenous sediment of middle Quaternary to Recent make the third and uppermost unit. The chemical sedimentation phase correlates with Units IV, III, and II of Site 380, and the terrigenous phase with Unit I of Site 380.

According to Hsü (this volume, B), the black shale sequence is generally free of carbonates, and foraminifer content suggests deposition in the marine-brackish seas of the Paratethys (Table 11). The periods of intermittent chemical sedimentation started with a regression when marine waters started to flow into the then essentially evaporitic Mediterranean. Evaporation rates were high, causing a reduction in Black Sea level, leading to a saline lake, and resulting in deposition of the clastic and dolomitic deposits at Sites 380 and 381 , and eventually subaerial erosion. In the Pliocene, the Black Sea was flooded by marine to brackish waters, and aragonitic mud deposits were formed. As the supply of fresh water increased, salinity was reduced and calcitic and sideritic sedimentation prevailed. During this time, terrigenous deposition was relatively slight compared to chemical sedimentation. Seekreide was deposited at periods of time when the Black Sea environment was compatible to that of present Lake Zurich. During even warmer times, siderite sediments were deposited, perhaps because of the increase in iron from waters draining into the Black Sea.

The increase in terrigenous sedimentation is thought by Hsü (this volume, B) to have been related to the time when the Danube changed to its present course (about a million years ago) and directly entered the Black Sea. If this is true, it also follows that the present Danube delta and its offshore parts were formed within the last million years. He bases this idea on field observations in Romania. The uplift of the Precarpathian basins of Romania were responsible for the change in the Danube drainage pattern, allowing it to directly enter into the Black Sea, whereas before it deposited most of its sediment in the Pannonian and Dacian basins. When the Danube, with its large terrigenous load, entered the Black Sea, it would have caused a cessation of chemical deposition and a change to terrigenous sedimentation. This change occurs at the base of his Unit I , at 332 meters subbottom depth, at Site 380 , and he dates it as midQuaternary.

Variations in climate increased as the Glacial age began. Hsü believes that, during glacial times, the Black Sea was more of a fresh-water lake, whereas in interglacial times its salinity was more brackish, either due to increases in evaporation or influx of marine water.

Hsü's interpretation of the pollen data is that continental glaciers began somewhere near the beginning of the Quaternary period about 1.5 to 2 million years ago, and that a long glacial period (termed Alpha glaciation) may have lasted for as much as one-half million years, followed by two interglacial (A and B) and two glacial (Beta and Gamma) stages (see Figure 5). These glacial periods definitely correlate with those of northwestern Europe.

Hsü estimates sedimentation rates (mainly using data from Site 380) at about $10 \mathrm{~cm} / 1000 \mathrm{yr}$ or less during the 
TABLE 9

Summary of Major Sedimentary Units, Ages, and Sedimentation Rates (as estimated by Stoffers, Degens, and Trimonis, this volume)

\begin{tabular}{|c|c|c|c|}
\hline Unit & Lithology & Sedimentation Rate & Age \\
\hline 1 & Coccolith ooze & $10-30 \mathrm{~cm} / 1000 \mathrm{yr}^{\mathrm{a}}$ & Holocene \\
\hline 2 & Sapropel & $10 \mathrm{~cm} / 1000 \mathrm{yr}^{\mathrm{a}}$ & Holocene \\
\hline 3 & Terrigenous mud & $1 \mathrm{~m} / 1000 \mathrm{yr}^{\mathrm{a}}$ & $\begin{array}{c}\text { Weichselian (New Euxine) } \\
60,000 \text { years at base }\end{array}$ \\
\hline 4 & $\begin{array}{l}\text { Nannofossil-rich } \\
\text { terrigenous mud }\end{array}$ & $\begin{array}{l}10-30 \mathrm{~cm} / 1000 \mathrm{yr} \\
\text { (based on similarity } \\
\text { to Unit } 1 \text { above) }\end{array}$ & $\begin{array}{l}\text { Eemian (Karangat) } \\
50-60,000 \text { years for } \\
\text { deposition of entire } \\
\text { unit) }\end{array}$ \\
\hline 5 & Sapropel & $\begin{array}{l}10 \mathrm{~cm} / 1000 \mathrm{yr} \\
\text { (based on similarity } \\
\text { to Unit } 2 \text { above) }\end{array}$ & $\begin{array}{l}\text { Eemian (Karangat) } \\
\text { Age of } 120,000-125,000 \\
\text { years at base }\end{array}$ \\
\hline 6 & Terrigenous mud & $\begin{array}{l}1 \mathrm{~m} / 1000 \mathrm{yr} \\
\text { (based on similarity } \\
\text { to Unit } 3 \text { above) }\end{array}$ & $\begin{array}{l}\text { Saalian (Post Uzunlar) } \\
80,000 \text { to } 1,000,000 \\
\text { years for entire unit; } \\
\text { total age of about } \\
200,000 \text { at base }\end{array}$ \\
\hline 7 & $\begin{array}{l}\text { Nannofossil-rich } \\
\text { terrigenous mud }\end{array}$ & None given by authors & Holsteinian (Uzunlar) \\
\hline 8 & Terrigenous mud & None given by authors & Elsterian (Old Euxine) \\
\hline 9 & $\begin{array}{l}\text { Terrigenous mud } \\
\text { with some carbonate } \\
\text { sediments }\end{array}$ & None given by authors & $\begin{array}{l}\text { Cromerian } \\
\text { Assumed age of } 700,000 \\
\text { at base }\end{array}$ \\
\hline 10 & $\begin{array}{l}\text { Sapropelic clay with } \\
\text { diatoms, siderite, } \\
\text { and varved clays }\end{array}$ & None given by authors & Menap-Waal \\
\hline 11 & Seekreide & None given by authors & $\begin{array}{c}\text { Eburon - assumed age of } \\
1,700,000 \text { at base }\end{array}$ \\
\hline 12 & $\begin{array}{l}\text { Diatomaceous sapro- } \\
\text { pelic clay with } \\
\text { siderite }\end{array}$ & None given by authors & $\begin{array}{l}\text { Tiglian - assumed age of } \\
2,200,000 \text { at base }\end{array}$ \\
\hline 13 & $\begin{array}{l}\text { Diatomaceous } \\
\text { seekreide }\end{array}$ & None given by authors & None given by authors \\
\hline 14 & $\begin{array}{l}\text { Sapropelic clay } \\
\text { with diatoms }\end{array}$ & None given by authors & Plio-Pleistocene boundary \\
\hline 15 & $\begin{array}{l}\text { Black siltstone } \\
\text { with intercalated } \\
\text { dolostones }\end{array}$ & None given by authors & Pliocene to late Miocene \\
\hline 16 & $\begin{array}{l}\text { Black siltstone with } \\
\text { intercalated breccia } \\
\text { and then siderite } \\
\text { layers }\end{array}$ & None given by authors & Late Miocene \\
\hline
\end{tabular}

pre-glacial times of chemical and black shale deposition, at about $30 \mathrm{~cm} / 1000 \mathrm{yr}$ during the Alpha Glacial stage, and perhaps as much as $60 \mathrm{~cm} / 1000 \mathrm{yr}$ after the Danube established its present drainage pattern. The sedimentation rate during the Würm may have been as high as $90 \mathrm{~cm} / 1000 \mathrm{yr}$, and during the Holocene $10 \mathrm{~cm} / 1000 \mathrm{yr}$. He concludes that the average glacial and interglacial sedimentation rate was about $50 \mathrm{~cm} / 1000$ years.

Hsü proposes that the ancient Black Sea was a deep-water body during much of the time represented in the sediments penetrated by the drilling, the main exception being during the early phase of chemical sedimentation when the supratidal dolomite formed. The bottom waters were at times oxygenated and at times anaerobic, but generally the Black Sea was a fresh-water lake during much of the last few million years.

\section{INORGANIC GEOCHEMICAL STUDIES}

\section{Major and Minor Element Analysis}

Two major studies were made of the major and minor elemental components of the Black Sea sediments (Emelyonov et al., this volume; Calvert and Batchelor, this volume). The Soviet group studied material from all three sites, whereas Calvert and Batchelor worked only on Hole 379A.

Considering the Emelyonov et al. research first, they analyzed the major components $\left(\mathrm{CaCO}_{3}, \mathrm{SiO}_{2}\right.$ amorph, $\mathrm{Fe}$, $\mathrm{Mn}, \mathrm{Ti}, \mathrm{P}, \mathrm{K}, \mathrm{Na})$ as well as 24 minor elements $(\mathrm{Cu}, \mathrm{Zn}$, $\mathrm{Ni}, \mathrm{Co}, \mathrm{Cr}, \mathrm{V}, \mathrm{Cd}, \mathrm{Li}, \mathrm{Rb}, \mathrm{Cs}, \mathrm{Sn}, \mathrm{Se}, \mathrm{Mo}, \mathrm{W}, \mathrm{F}, \mathrm{B}, \mathrm{La}$, $\mathrm{Th}, \mathrm{Hf}, \mathrm{Sc}, \mathrm{Eu}, \mathrm{Sb}, \mathrm{Ce}, \mathrm{Ta})$. They discuss their results or each hole and relate them to the different sedimentary units. A vast and impressive amount of data is presented. 


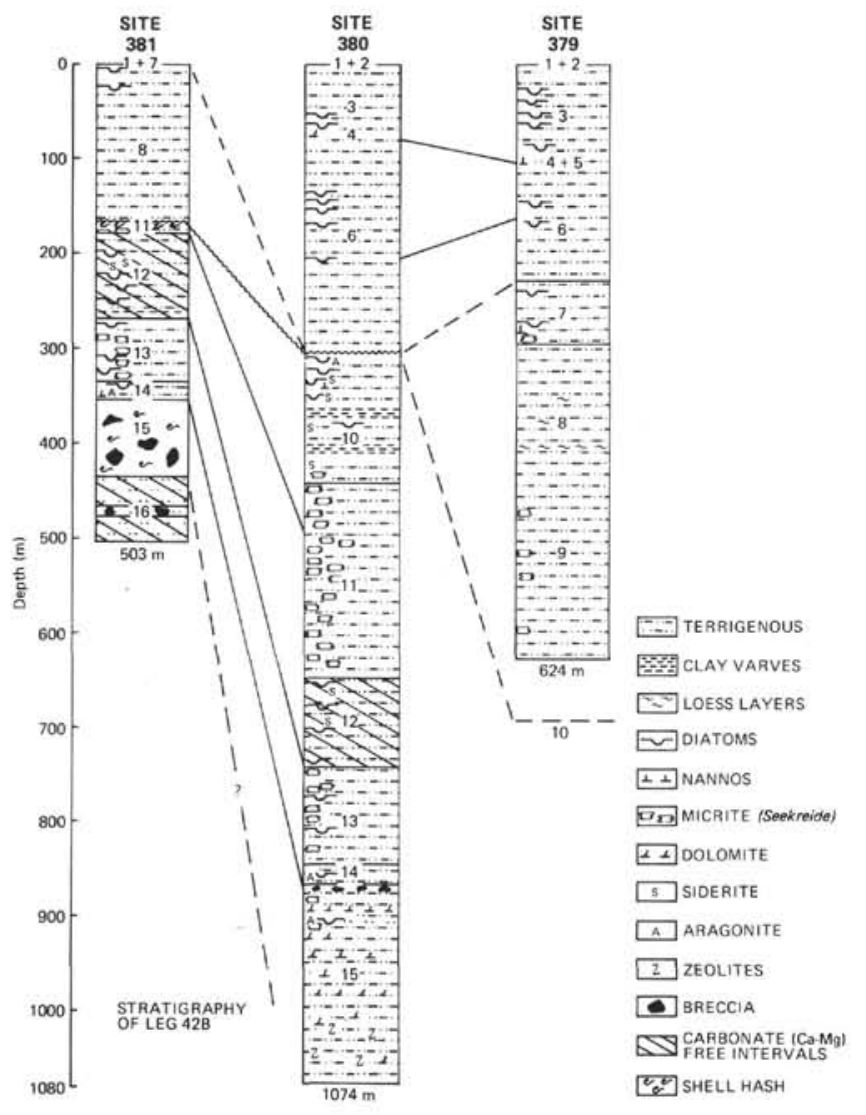

Figure 7. Stratigraphy of Leg $42 B$ sediments based on work of Stoffers et al., this volume. Unit 1: Nannofossil ooze; Unit 2: Sapropel; Unit 3: Terrigenous mud; Unit 4: Nannofossil-rich terrigenous mud; Unit 5: Sapropel; Unit 6: Terrigenous mud; Unit 7: Terrigenous mud with nannofossils; Unit 8: Terrigenous mud with abundant turbidites; Unit 9: Terrigenous mud with carbonate cycles; Unit 10: Sapropelic clay with diatoms, nannofossils, siderite and varved clays; Unit 11: Seekreide; Unit 12: Sapropelic diatomaceous clay with siderite; Unit 13: Diatomaceous seekreide; Unit 14: Sapropelic clay with diatoms, nannofossils, and aragonite; Unit 15: Black siltstone with intercalated dolostones (partially brecciated) aragonite, calcite, and zeolites; Unit 16: Black siltstone with an intercalated breccia.

Many of the chemical variations are clearly related to sediment type or depositional environment. For example, interglacial sediments (as defined by shipboard and Soviet studies) show higher average contents of Corg and $\mathrm{Si}_{2}$ amorph. Glacial deposits from both Sites 379 and 380 are mainly terrigenous (non-calcareous and low calcareous) clays low in organic matter. The amount of total carbonate or other mineral composition also has an effect on some metal content.

In many instances the average content and ratios of certain elements reflects the source rocks for the sediments. For example, the sediments from Site 379 show the strong influence of Pleistocene weathering of basic, ultrabasic, and intermediate rock types. Material from Site 380, in contrast to 379 , tends to have somewhat higher contents of $\mathrm{Li}, \mathrm{Rb}$, and $\mathrm{Zn}$ and lesser amounts of $\mathrm{Cu}, \mathrm{Ni}, \mathrm{Co}, \mathrm{Cr}$, and $\mathrm{Se}$. This difference reflects the larger amount of weathering products from acid and intermediate source rocks in the Site 380 area as compared to the more basic rock types from the Site 379 source area. Sediments from Site 381 have a similar source area (acid and intermediate rocks) as Site 380 .

Pliocene sediments, first reached in Hole $380 \mathrm{~A}$, tend to have the upper part of their section enriched in organic matter and $\mathrm{SiO}_{2}$ amorph. Some high amounts of $\mathrm{Fe}$ and $\mathrm{Mn}$ are found, as expected in the siderite layers. One of the siderite interbeds from Site 380 was studied microscopically and a relict structure was found, suggestive of siderite substitution of a diatomaceous mud.

The Pliocene and Miocene sediments from Holes 380A and 381 differ considerably from the Pleistocene sediments, both in $\mathrm{CaCO}_{3}$ content and distribution. In the older sediments, alternating high and low concentrations of carbonates are common (see Site Chapter core descriptions), but these are not found in the Quaternary sediments. Siderite is likewise absent from the Quaternary section, but occurs in the older sediments.

The maximum contents of $\mathrm{V}, \mathrm{Fe}, \mathrm{Ni}, \mathrm{Cu}, \mathrm{Cr}, \mathrm{Mn}, \mathrm{Ti}$, $\mathrm{Zn}$, and $\mathrm{Pb}$ found in the recent deep-water sediments come from sedimentary material carried into the Black Sea from the southern drainage area. The principal source of the Fe, $\mathrm{Ni}, \mathrm{Cr}, \mathrm{Zn}, \mathrm{Pb}$ maximums are mainly from the Eastern Pontic drainage system. $\mathrm{Pb}$ is the only element that is closely correlated with the Danube system, and is found in high amounts over large areas near the river mouth. Emelyonov et al. conclude that the principal elemental differences in the Pleistocene sediments are the result of variations in amount and quality of source material from the different drainage areas. Organic carbon and $\mathrm{SiO}_{2}$ amorph are strongly influenced by climatic conditions.

Calvert and Batchelor (this volume) analyzed about 60 samples from Hole 379A by X-ray emission spectrometry; carbon was analyzed by combustion. Determinations were reported of $\mathrm{SiO}_{2}, \mathrm{Al}_{2}, \mathrm{O}_{3}, \mathrm{TiO}_{2}, \mathrm{Fe}_{2} \mathrm{O}_{3}, \mathrm{Ca} 0, \mathrm{Mg} 0, \mathrm{~K}_{2} \mathrm{O}$, $\mathrm{P}_{2} 05, \mathrm{MnO}, \mathrm{S}, \mathrm{CO}_{2}, \mathrm{C}, \mathrm{As}, \mathrm{Ba}, \mathrm{Br}, \mathrm{Cu}, \mathrm{I}, \mathrm{Mo}, \mathrm{Ni}, \mathrm{Pb}, \mathrm{Rb}$, $\mathrm{Sr}, \mathrm{Y}, \mathrm{Zn}$, and $\mathrm{Zr}$. Their data from this site are strongly influenced by the terrigenous nature of these sediments (sediments of more chemical origin were found only at Sites 380 and 381). A large amount of variation in the data results from the laminated aspect of the sediments and by the sampling pattern, i.e., sands versus silts or clays, etc., or various mixtures of carbonate, terrigenous, or biogenous sediments.

Variations in organic carbon and total sulfur correlate fairly well. The highest value for both is found in a sapropel layer at 99 meters subbottom depth $(14.75 \% \mathrm{C}, 1.81 \% \mathrm{~S})$. This sample also has highest amounts of $\mathrm{As}, \mathrm{Br}, \mathrm{Cu}, \mathrm{Mo}, \mathrm{P}$, and $\mathrm{Mn}$, and is similar geochemically to the shallow sapropel known from piston coring (Unit 2 of Site 379 and Unit $\mathrm{Ib}$ of 380). The sapropelic sediments studied by Calvert and Batchelor have little terrigenous sediment influence. The authors recognized four organic - and pyrite-rich muds and noted that they coincided with peaks in the pore-water chlorinity curve. They feel that this supports earlier suggestions that such deposits can be formed when the environment changes from fresh water to saline conditions. The presence of pyrite supports this conclusion, because it is controlled by, among other things, the availability of sulfate from sea water. The data of Calvert and Batchelor suggest three marine episodes in the upper part of Hole 379A. Diatom 


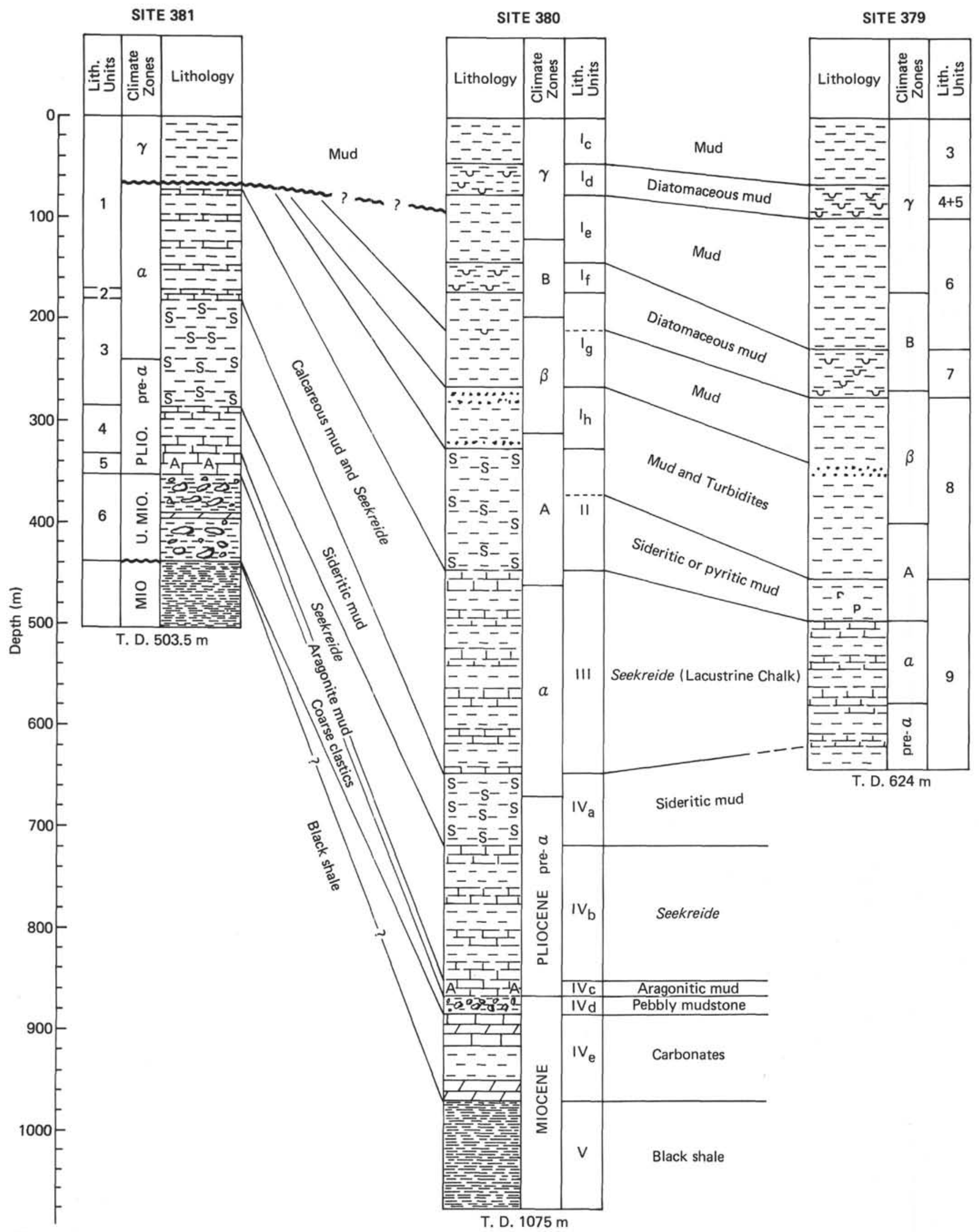

Figure 8. Correlation of lithologic units at the three sites, according to Hsï (this volume, A).

data (Schrader, this volume) support this view, although he notes four such marine periods (this difference is probably due to the lesser amount of samples examined by Calvert and Batchelor). 
TABLE 10

Tentative Correlation of Sites $379, \mathbf{3 8 0}$, and 381 Based on Post-Cruise Meeting

\begin{tabular}{|c|c|c|}
\hline Hsü (380) & $\begin{array}{l}\text { Stoffers and Degens } \\
\quad(370 \text { and } 381)\end{array}$ & $\begin{array}{l}\text { Tentative Age } \\
\text { (see text) }\end{array}$ \\
\hline $\mathrm{I}_{\mathrm{a}}$ and $\mathrm{I}_{\mathrm{b}}$ & 1 and $2(379)$ & Holocene \\
\hline $\mathrm{I}_{\mathrm{c}}$ & $3(379)$ & Weichselian/Würm \\
\hline $\mathrm{I}_{\mathrm{d}}$ & 4 and $5(379)$ & $\begin{array}{l}\text { Eemian/Riss-Würm Inter- } \\
\text { glacial }\end{array}$ \\
\hline $\mathrm{I}_{\mathrm{e}}$ & $6(379)$ & $\begin{array}{l}\text { Saalian/Riss (Stoffers and } \\
\text { Degens) Glacial and Inter- } \\
\text { glacial (Hsü) }\end{array}$ \\
\hline$I_{f}$ & 7 (379) & $\begin{array}{l}\text { Holsteinian (Stoffers and } \\
\text { Degens) Interglacial B } \\
\text { (Hsü) }\end{array}$ \\
\hline $\begin{array}{l}\mathrm{I}_{\mathrm{g}} \\
\mathrm{I}_{\mathrm{h}}\end{array}$ & $8(379)$ & $\begin{array}{l}\text { Elster/Mendel (Stoffers } \\
\text { Degens) Glacial B (Hsü) }\end{array}$ \\
\hline II & $\begin{array}{l}9 \text { and deeper } \\
(379)\end{array}$ & $\begin{array}{l}\text { About } 800,000 \text { (Stoffers } \\
\text { and Degens) }\end{array}$ \\
\hline II and III & $9(379)$ & Plio/Quat (Hsü) \\
\hline III & $2(381)$ & $\begin{array}{l}\text { Eburon (cold period about } \\
1.7 \times 10^{6}-\text { Stoffers and } \\
\text { Degens) }\end{array}$ \\
\hline III & $\begin{array}{l}\text { Part of } 9(379) \\
\text { and } 2(381)\end{array}$ & $\begin{array}{l}\text { Alpha (glacial - about } 2 \times \\
10^{6} \mathrm{Hsü)}\end{array}$ \\
\hline $\mathrm{IV}_{\mathrm{a}}$ & $3(381)$ & $\begin{array}{l}\text { Tiglian }\left(2.2 \times 10^{6} \text { base - }\right. \\
\text { Stoffers and Degens) } \\
\text { U. Pliocene (Hsü) }\end{array}$ \\
\hline $\mathrm{IV}_{\mathrm{b}}$ & $4(381)$ & $\begin{array}{l}\text { Pretiglian (Stoffers and } \\
\text { Degens) M-L Pliocene (Hsü) }\end{array}$ \\
\hline $\mathrm{IV}_{\mathrm{c}}$ & $5(381)$ & $\begin{array}{l}\text { About } 2.6 \times 10^{6} \text { or } \\
\text { younger (Stoffers and } \\
\text { Degens) L. Pliocene (Hsü) }\end{array}$ \\
\hline $\mathrm{IV}_{\mathrm{d}, \mathrm{e}}$ and $\mathrm{V}_{\mathrm{a}}$ & $6(381)$ & $\begin{array}{l}\text { Pliocene (or possibly older } \\
\text { - Stoffers and Degens) }\end{array}$ \\
\hline $\mathrm{IV}_{\mathrm{d}}$ & $6,7,8$ & L. Miocene (Hsü) \\
\hline $\mathrm{V}_{\mathrm{b}}$ & $\begin{array}{l}\text { Uncored Zeolite } \\
\text { Interval }\end{array}$ & $\begin{array}{l}\text { Pliocene? (Stoffers and } \\
\text { Degens) }\end{array}$ \\
\hline $\mathrm{IV}_{\mathrm{e} \text { and }} \mathrm{V}_{\mathrm{a}}$ & 9 & Miocene (Hsü) \\
\hline $\begin{array}{l}>V_{b} \\
>V_{b} \\
>V_{b}\end{array}$ & $\begin{array}{l}7 \\
8 \\
9\end{array}$ & $\begin{array}{l}4-5 \times 10^{6} \text { (Stoffers and } \\
\text { Degens) }\end{array}$ \\
\hline
\end{tabular}

Calvert and Batchelor used an R-mode factor analysis to determine elemental associations. Five factors accounted for $97.5 \%$ of the total variance.

Factor 1 represents organic and sulfide-rich samples that also have high $\mathrm{Sr}$ values (because of the presence of coccoliths and aragonite), as well as minor metal and $\mathrm{Mn}$ and $\mathrm{Br}$ associations. This factor accounts for $43.1 \%$ of the total variance.

Factor 2 represents feldspar and has high loadings for $\mathrm{K}_{2} \mathrm{O}, \mathrm{Al}_{2} \mathrm{O}_{3}, \mathrm{Fe}_{2} \mathrm{O}_{3}, \mathrm{Fe}_{2} \mathrm{O}_{3}, \mathrm{Rb}, \mathrm{Pb}, \mathrm{Y}$, and $\mathrm{Zn}$, and moderately high loadings for $\mathrm{TiO}_{2}$ and $\mathrm{Ba}$. This factor accounts for $23.1 \%$ of the total variance.

Factor 3 is a bipolar factor representing the negative correlation between the amounts of $\mathrm{CaO}_{3}$ and sand throughout the hole. It contains positive loadings for $\mathrm{CaO}, \mathrm{CO}_{2}$, and $\mathrm{Sr}$, and negative loadings for $\mathrm{SiO}_{2}, \mathrm{Al}_{2} \mathrm{O}_{3}$, and $\mathrm{Zr}$, and accounts for $18 \%$ of the variance.
Factor 4 is interpreted as a chlorite factor, and has high loadings for $\mathrm{MgO}$ and $\mathrm{Ni}$, and moderately high loadings for $\mathrm{TiO}_{2}$ and $\mathrm{Fe}_{2} \mathrm{O}_{3}$. It accounts for $9.0 \%$ of the variance.

Factor 5 probably represents a heavy mineral association, with ilmenite, zircon, monazite, and apatite the most likely minerals, and contains significant loadings for $\mathrm{TiO}_{2}, \mathrm{P}_{2} \mathrm{O}_{5}$, $\mathrm{Y}$, and $\mathrm{Zr}$. It accounts for $4.3 \%$ of the variance.

Sulfer distribution in sediments from Site 380 was studied by Berner and Holdren (this volume). They only examined frozen samples, but apparently these samples had not withstood air oxidation during storage. Many samples described as black in color had changed to brown, indicating the oxidation of black, pigmenting $\mathrm{FeS}$ minerals (greigite, mackinawite) to brown ferric oxides. The authors propose that the relatively low water content of the sediments caused an insufficient protective ice coating over the potentially oxidizable sediment grains. 
TABLE 11

Milestones of Geologic History of the Black Sea, as Recorded by the Sediments at Site $\mathbf{3 8 0}$

(from Hsü, this volume)

\begin{tabular}{|c|c|c|c|c|c|}
\hline $\begin{array}{l}\text { Depth } \\
\text { (m) }\end{array}$ & Core & $\begin{array}{l}\text { At or Near } \\
\text { Base of Unit }\end{array}$ & Event & Stage & $\begin{array}{l}\text { Estimated } \\
\text { Age (m.y.) }\end{array}$ \\
\hline 1070 & $380 \mathrm{~A}-80$ & V & $\begin{array}{l}\text { Disappearance of } \\
\text { Engelhardtia flora }\end{array}$ & Late Tortonian? & $8-10 ?$ \\
\hline 988 & $380 \mathrm{~A}-70$ & $\mathrm{IV}_{\mathrm{e}}$ & $\begin{array}{l}\text { Extinction of endemic } \\
\text { Paratethys marine-brackish } \\
\text { foraminifer fauna }\end{array}$ & Messinian & 6 \\
\hline 883.5 & $380 \mathrm{~A}-59$ & $\mathrm{IV}_{\mathrm{d}}$ & $\begin{array}{l}\text { Deposition of coarse } \\
\text { clastics began; Para- } \\
\text { tethys water had been } \\
\text { drained into Mediterranean; } \\
\text { shallow Black Sea }\end{array}$ & Late Messinian & 5.5 \\
\hline 864.5 & $380 \mathrm{~A}-57$ & $\mathrm{IV}_{\mathrm{c}}$ & $\begin{array}{l}\text { Marine invasion of Black } \\
\text { Basin }\end{array}$ & Earliest Pliocene & 5.2 \\
\hline 718 & $380 A-56$ & $\mathrm{IV}_{\mathrm{a}}$ & $\begin{array}{l}\text { Siderite sedimentation } \\
\text { in brackish late began }\end{array}$ & Pliocene & - \\
\hline 644 & $380 \mathrm{~A}-34$ & III & $\begin{array}{l}\text { Main epoch of Seekreide } \\
\text { sedimentation in deep, } \\
\text { fresh lake began }\end{array}$ & Earliest Pliocene & 1.7 \\
\hline 496.5 & $380 \mathrm{~A}-12$ & II & $\begin{array}{l}\text { Siderite sedimentation } \\
\text { in brackish lake began }\end{array}$ & $\begin{array}{l}\text { Pleistocene } \\
\text { (Interglacial A) }\end{array}$ & \\
\hline 332.5 & $380-36$ & $\mathrm{I}_{\mathrm{h}}$ & $\begin{array}{l}\text { Chemical sedimentation } \\
\text { practically ceased, } \\
\text { Danube drained into } \\
\text { the Black Sea, which was } \\
\text { gradually turned into a } \\
\text { fresh-water lake }\end{array}$ & Glacial & $0.6-$ \\
\hline 171 & $380-18$ & $\mathrm{I}_{\mathrm{f}}$ & $\begin{array}{l}\text { Salinization of Black Sea } \\
\text { at times, perhaps Bosporus } \\
\text { was eroded down to inter- } \\
\text { glacial sea level }\end{array}$ & & \\
\hline 76 & $380-8$ & $\mathrm{I}_{\mathrm{d}}$ & $\begin{array}{l}\text { Major marine invasion } \\
\text { during an episode of } \\
\text { warm climate }\end{array}$ & $\begin{array}{l}\text { Late Pleistocene } \\
\text { Karangat Terraces }\end{array}$ & 0.125 \\
\hline 2 & $380-1$ & $\mathrm{I}_{\mathrm{b}}$ & Old Black Sea & & 0.007 \\
\hline
\end{tabular}

Total sulfur, which is unaffected by air oxidation, had relatively high values ranging from $0.01 \%$ to $1.70 \%$ sulfur by dry weight. These values represent primarily reduced forms of sulfur or all forms of sulfur other than sulfate. The contribution of sulfate from the interstitial water of the sediments could provide at most about $0.1 \% \mathrm{~S}$ by dry weight. Thus, bacterial sulfate reduction, the ultimate process responsible for most of the reduced sulfur, has been effective over the period covered by the sediments from Site 380. In addition, bacterial sulfate reduction will only occur under anaerobic conditions, which means the pore waters were anoxic also during this period.

Berner and Holdren attempted to confirm the shipboard report of abundant siderite, but could not detect it. If it was present, it was probably oxidized prior to their analysis.

\section{Radioactive Isotope Studies}

$\mathrm{C}^{14}$ studies made by Diverts et al. (this volume) did not yield much new information about sediment age. Seven analyses (with one exception) showed ages greater than 22,000 years. Two samples from piston cores had younger ages. The distribution of the radioactive isotopes of $\mathrm{K}, \mathrm{Ra}$, and Th were also determined, and content of these radioisotopes is similar to that of other oceans.
Krylov and Trimonis (this volume) studied the age of selected samples by the Potassium-Argon method from the three sites. They used the ages determined on terrigenous material of varying grain sizes in an attempt to correlate them with that of rocks in the drainage area of the Black Sea. The various drainage areas, according to their study and earlier papers by Krylov, can be characterized generally by relatively narrow age ranges, i.e., Russian Platform (drained by the Bug and Dnieper rivers) is 1080-1260 million years, the Danube 200-225 million years, the Caucasus rivers 195-670 million years.

The technique, which at least in the above paper, does not seem to account for mixtures of sediments from different source areas or from changes (by erosion within a source area, showed that, in the recent sediments, the coarsegrained interbeds (turbidite layers) are of different ages600-800 million years in the central basin, suggesting a source from the Russian Platform, but 67-75 million years in the eastern portion suggesting a source from the eastern Pontic Rivers.

In samples from Site 379, Krylov and Trimonis, noted that the Potassium-Argon age was relatively constant, ranging from 114 to 204 million years, suggesting a constant source which was from various areas-Turkey, the northern 
portions of the drainage area, from the Caucasus. Sites 380 and 381 had a more variable sediment supply with much of the material apparently coming from the south and southwest, from the north (Danube) and from the Russian Platform. A future comparison of this technique (using the same samples), with conventional heavy-mineral methods and the strontium method of Nardone and Faure (this volume) would be informative.

\section{Non-Radioactive Isotopes}

Nardone and Faure (this volume) studied the strontium isotope composition of sediments collected from Site 379. They showed that $\mathrm{Sr}$ concentrations and the $\mathrm{Sr}^{87} / \mathrm{Sr}^{86}$ ratio of the detrital non-carbonate fraction from this site were controlled, to a first approximation, by varying proportions of sialic and mafic source material. The sialic portion came from weathering products of Precambrian to Tertiary age igneous, metamorphic, and sedimentary rocks in the northern watershed. The mafic portion came from Mesozoic to Cenozoic ophiolite complexes and associated volcanic rocks and volcanogenic sediments from Turkey and Bulgaria.

Using this two-component model, Nardone and Faure found that the concentrations of the sialic component varied systematically as a function of depth in Hole 379. In addition, there appears to be a strong climatic influence on the supply of the sialic detritus from the northern watershed, probably because of the advances and retreats of the continental glaciers. On the other hand, the amount of sediment transported and supplied by the rivers from Turkey and Bulgaria during this time probably was fairly constant because the area was ice free.

The $\mathrm{Sr}^{87} / \mathrm{Sr}^{86}$ ratios from the calcium carbonate fraction (Cores 1 through 22) fell in the range of 0.7070 to 0.7084 , which is less than their ratio in sea water $(0.709)$. The authors attribute this to the presence of reworked older coccoliths that have lower $\mathrm{Sr}^{87} / \mathrm{Sr}^{86}$ ratios than the modern forms. Tye isotopic composition of $\mathrm{Sr}$ in the carbonate phases can have use as an indicator of salinity in the Black Sea. This is shown by the fact that the isotope ratio of carbonates deposited during the Würm/Riss Interglacial is greater than that of the Würm Glacial period, probably because of the predominance of the indigenous species Emiliania huxleyi during the periods of increased salinity (interglacials) in the Black Sea.

Oxygen and carbon isotopes $\left(0^{18}\right.$ and $\left.\mathrm{C}^{13}\right)$ from carbonate sediments were studied by Deuser, Degens, and Stoffers (this volume). They believe that the oxygen isotopes underwent considerable post-depositional exchange, whereas the carbon isotopes generally concurred with the paleontological and sedimentological evidence indicating frequent changes in the depositional environment. The authors noted that the complex interplay of factors within the Black Sea environment make it essentially impossible to use the isotope ratios for paleotemperature determinations, although they can be used to establish general trends. Factors influencing the isotopes include volume and location of river discharge, supply of Mediterranean water, climate, currents, and depth of halocline. Their data show some of the major environmental events such as the shallow-water phase near the Pliocene-Miocene boundary.

\section{Interstitial Water}

Two relatively detailed studies of interstitial waters were made by Shiskina (this volume) and by Manheim and Schug (this volume).

Shiskina studied the distribution of bromine, chloride/ bromide ratios, and iodine, in the interstitial waters of the Black Sea sediments. Usually, chloride and bromide ions will have similar chemical and geochemical properties and behavior because of their similar ionic radii. In interstitial waters, differences between chloride and bromide can occur because of the greater solubility of bromide than chloride during sea-water evaporation up to the deposition of $\mathrm{NaCl}$. The $\mathrm{C} 1 / \mathrm{Br}$ ratio in the ocean generally is about 293 . Deviations from this value may indicate various geochemical processes.

Iodine can be enriched in interstitial waters during the breakdown of organic matter. It is especially apparent in marine sediments from regions of high productivity.

\section{Site 379}

The upper section of this site (above $268 \mathrm{~m}$ ) shows low chlorinity, indicating freshening of the basin during the period when these sediments were deposited (the Neoeuxinian). From 268 to 621 meters chlorinity slowly increases to $20.92 \%$, a value higher than that found in the modern ocean. This result was also noted by the shipboard party (see Site Reports). The concentration of bromine in pore waters is similar to that of chloride. Below 336.4 meters, bromide increases and the $\mathrm{C} 1 / \mathrm{Br}$ ratio varies between 166 and 199, considerably lower than ocean waters. The source of the chloride and bromide in the interstitial waters at these depths may be brines formed by sea-water evaporation prior to the precipitation of $\mathrm{NaCl}$, resulting in waters relatively richer in bromide than chloride.

Iodine concentration in the pore fluids of this site is high. The concentration in upper layers $(2.1 \mathrm{mg} / \mathrm{kg})$ is 50 times higher than sea water. Iodine continues to increase with depth and at 583.2 meters reaches $41.6 \mathrm{mg} / \mathrm{kg}$. This enrichment is most probably due to mineralization of organicrich sediments.

\section{Site 380}

The pore waters from this site also show the upper fresh-water stage of the basin. Likewise the chlorinity increases with depth. The bromide and $\mathrm{C} 1 / \mathrm{Br}$ ratio at this site may provide an answer to the source of the brines and mechanism of their emplacement. $\mathrm{C1} / \mathrm{Br}$ ratio is well above 300 , suggesting that the pore fluids are influenced by waters that have leached salt deposits. Leaching of halite will produce waters having high concentrations of chloride and low concentrations of bromide.

\section{Site 381}

The upper fresh-water stage is not present, reflecting the stratigraphic unconformities at this site. With depth, salinities increase, but the $\mathrm{C} 1 / \mathrm{Br}$ ratio stays near 300 , which is interesting, considering the increase in total chlorinity.

Shishkina concludes that the increased concentrations of chloride and bromide from depths to 600 meters at Site 379, 
and the relative enrichment in bromine, are associated with hypersaline brines that formed from evaporation of sea water but before deposition of $\mathrm{NaC} 1$. At Site 380 the pore waters are more enriched in iodine, which is probably the result of the mineralization of organic matter and the liberation of decomposition products.

Manheim and Schug, in their study of interstitial waters, noted three main features from the Black Sea. The first is a clear indication of a fresh-water stage detectable in the upper section of Sites 379 and 380 (probably removed by erosion at Site 381). The upper portion of this fresh-water phase previously had been detected from piston core studies. At Site 379 , this phase extends to over 200 meters subbottom depth, but is much shallower at Site 380 .

Their second point is the observation of a hypersaline episode below the fresh-water zone. They differ from Shiskina in feeling that there was not permanent evaporite deposition, at least in the immediate vicinity of the drill sites. Below this hypersalinity zone, Manheim and Schug found normal marine salinities underlying a poorly permeable and tightly cemented limestone and dolomite sequence (at Site 381 in Miocene sediments). They interpreted this to mean that no evaporite deposition took place at this site, at least back to middle-late Miocene time, and this possibly may also apply for the rest of the Black Sea. It is possible that halite was locally deposited and then redissolved, or that salt fluids migrated to the present position. The authors believe that this hypersaline (probably more like a playa lake) phase took place in the Pleistocene, perhaps just before Mindel-Riss (Drevne- or Old-Euxinian) time.

Thirdly, they note several strong diagenetic changes, such as $\mathrm{NH}_{4}$ concentrations being considerably higher than $\mathrm{K}$ in the pore waters, an absence of $\mathrm{SO}_{4}$, and reaction of both $\mathrm{Mg}$ and $\mathrm{Na}$ with calcium phases that liberated $\mathrm{CaCl}_{2}$ and formed diagenetic minerals. Diatom-rich zones also are higher in silica concentrations, whereas clayey sediment areas lack amorphous silica.

\section{ORGANIC GEOCHEMICAL STUDIES}

The study of the organic geochemistry of the Black Sea sediments was one of the major priorities and objectives of the drilling program. The preliminary results reported below give new data on the initiation of catagenesis (late diagenesis) from an organic-matter rich setting. Information is also presented on the diagenesis of hydrocarbons and the degradation of porphyrins, amino acids, chlorophylls, carbohydrates, etc. Initially, it was planned that the entire hole would be cored for geochemistry at Site 379; however, the high sedimentation rate and the large amount of turbidites made this plan unrealistic. Nevertheless, numerous samples were taken; coupled with the total sampling program, an adequate suite of samples was obtained for the geochemists.

\section{Dissolved Gases in Black Sea Sediments}

Hunt and Whelan (this volume) studied the dissolved gases from all three sites. They found that the gases were mainly methane with small amounts of carbon dioxide and other hydrocarbon gases. Ethane content ranged from 1 to about $1000 \mathrm{ppm}$ by volume of total gas, propane from 1 to 100 ppm, butane from about 0.1 to $100 \mathrm{ppm}$, and pentane from 0.1 to $20 \mathrm{ppm}$. Carbon 13 data on some of the gas samples indicate that the methane is biological in origin. Concentrations of the higher hydrocarbons increased irregularly with depth. There were definite indications that the gas content correlated with lithology (for example, breccia had more methane, because of migration, which in turn resulted in a relatively lower concentration of the higher hydrocarbons).

The hydrocarbon gas data of Hunt and Whelan show that some gases are forming in situ, and are not due to diffusion of gases from depth. McIver (this volume) analyzed nine samples, eight from Hole $379 \mathrm{~A}$ and one from Hole $380 \mathrm{~A}$, for determination of residual gases. His results, like those of Hunt and Whelan, were that they contained moderate amounts of hydrocarbon gas, virtually all of which is methane. The values are similar to results from previous analyses of samples from earlier DSDP legs. Four additional frozen samples from Site 380 had moderate amounts of predominantly amorphous kerogen. These samples showed a low degree of thermal alteration, as did the low hydrocarbon to total bitumen ratio of the solvent extractables.

McIver concludes that the Black Sea sediments are not unusual, and that the moderate organic carbon (predominantly amorphous in nature) and high bitumen contents indicate that they could be good sources of oil (see later section). However, the low alteration index and low ratios of hydrocarbon to bitumens suggest that the sediments have not undergone sufficient thermal stress to have yet produced enough hydrocarbon for significant hydrocarbon migration to have occurred.

Schmitt, this volume, made isotope anlyses of the head space methane in samples from Sites 379 and 380 . He found that the $\delta^{13} \mathrm{C}$ values of the methane are in the range from $-70 \%$ to $-50 \%$ (PDB) and have a relationship to gaseous alkanes content.

Faber, Schmitt, and Stahl (this volume) also analyzed the isotope content in the head space methane. They found $\delta^{13} \mathrm{C}$ values in the range of $-70 \%$ to $-55 \%$ (PDB), similar to that of Schmitt (this volume). These values are typical for immature gases, and tend to slightly increase with depth. Methane enriched in $\delta^{13} \mathrm{C}$ might be related to a higher $\mathrm{CO}_{2} /$ $\mathrm{CH}_{4}$ ratio and may be explained by bacterial oxidation. The increase in the $\delta^{13} \mathrm{C}$ concentration can also be related to an increase in the total amount of methane. This follows, since the methane is formed by bacterial reduction of carbon dioxide, which generally is assumed to be the main methane-forming process in an immature organic source material. As this process occurs, it would generate isotopically light methane.

A start in thermocatalytic processes was indicated at Site 380 where the ethane/methane and iso-butane/n-butane ratios increase slightly with depth.

\section{Organic Matter in Black Sea Sediments}

Numerous papers have been written concerning various portions of the organic matter fraction. The highlights are described below, but the interested reader should consult the appropriate paper for the actual data. It should be emphasized that the organic matter content and character are strongly influenced by sediment type, and this in turn may result in 
apparent differences in analytical results due to sampling effects. Until a comprehensive study is made of the total organic content of the Black Sea, it is hard to evaluate which set of analyses best indicates the average value. Nevertheless, the data and results of the geochemical studies are fairly consistent.

Baker, Palmer, and Huang (this volume) studied early and intermediate chlorophyll diagenesis in sediments from all three sites. Their data showed very clearly the importance of burial depth for maturation. Shallow sediments contained chlorins similar to those from Pleistocene sediments from other DSDP sites. With depth, the chlorins were replaced with free-base porphyrins; in some places nickel porphyrins were found. The nickel porphyrins do not fit the expected sequence of chlorophyll diagenesis, and may have migrated to this location from deeper older sediments.

At Site 379, samples from as deep as 458 meters did not show any metal porphyrins, which indicates that chlorophyll diagenesis has not yet reached the intermediate depth at Site 379 . The nickel porphyrins were detected in the range of 484 to 526 meters from Hole $380 \mathrm{~A}$, but chlorins were abundant above and below this depth, suggesting migration of the former, since they are diagenetically out of place.

The porphyrin content at Site 381 differed when compared to stratigraphically correlative units at Site 380 . This observation is only based on a few samples from each site but, if true, clearly shows the importance of depth of burial as a determining factor in maturation. This factor and its corollary temperature may be more important than geological age in the maturation process of organic matter.

The distribution of sugars, amino acids, and some hydrocarbons was determined on selected samples from the three sites and from some previously collected cores (Mopper et al., this volume). Their data, like those of other Black Sea analysts, show how geochemical techniques can be used to ascertain variations in type of sedimentation inputs.

The distribution of amino acids tended to stay relatively uniform in spite of variations in sediment type and organic carbon content. Average concentrations were low, being about $7 \mathrm{mg} / \mathrm{g}$ in the younger sediments and less than $0.3 \mathrm{mg} / \mathrm{g}$ in the older sediments. The analyses of Mopper et al., show that within individual amino acid groups all the major protein-building forms are present. The absence of $\beta$-alanine is indicative of minimal diagenetic effects. The dominant amino acids are glycine, alanine, and serine, while ornithine is the dominant basic amino acid.

The distribution of sugars, compared to the amino acids is more variable. Mopper and his colleagues conclude that the sugar variations are mainly due to fluctuations in the form of the organic input, either being terrigenous or planktonic. The ratio of glucose to ribose reflects these changes. Sugar generally is relatively high in sediments having a relatively high organic carbon content. The source of the sugars is partly from plankton and partly from land plant debris, whereas the source of the amino acids is the plankton. Thus the larger amounts of terrigenous sediments in the upper parts of the sedimentary section is expressed by a relatively high sugar to amino acid ratio and the opposite tends to occur when, with depth, the amount of terrigenous deposition decreases.

Mopper et al. found, as did several other authors, that the quantity of hydrocarbons extracted was less than expected considering the organic content of the sediment.
Erdman and Schorno (this volume) analyzed sediment samples from Leg $42 \mathrm{~A}$ (Mediterranean) as well as 10 sediment sections from Site 380 . Their studies included: (1) the amount and type of organic matter present; (2) carbon isotope ratio values of the lipid and kerogen fractions; (3) elemental analysis of total nitrogen in the sediment and carbon, hydrogen, nitrogen, and sulfur content of the lipid fraction; and (4) the ratio of odd to even n-alkanes.

AT Site 380 the organic carbon content was higher tham $0.9 \%$ (except for one sample). The lipid fraction had a carbon isotopic composition in the depth interval from 29.4 to 228 meters that ranged from -29.1 and $-31.1 \delta \mathrm{C}^{13} \mathrm{PDB}$, typical of brackish- and fresh-water environments, to a relatively constant value of $-27.8 \pm 1.0 \beta \mathrm{C}^{13} \mathrm{PDB}$. A sample from the 927.9-meter section was an exception and had a carbon isotopic value typical of an open marine environment. The sediments showed a slight trend to heavier isotope ratio values with depth.

Nitrogen content ranged from a low of $187 \mathrm{ppm}$ in organic-lean terrigenous muds to $1420 \mathrm{ppm}$ for the organicrich sediments. This increase in total organic nitrogen with increasing organic content has been observed by the same authors from other DSDP sites.

Vuchev et al. (this volume) reported on preliminary results of geochemical studies of six sediment samples from Sites 379 and 381 . They analyzed both for organic and mineral components and noted that it took continued treatment with $\mathrm{HC} 1$ to extract a considecable part of the amino acids, which suggests to them that amino acids and higher molecular weight degradation protein products are intimately connected with the inorganic matrix. Carbonates are an important part of this matrix.

Whelan and Hunt (this volume) found light hydrocarbons at all three sites. $\mathrm{C}_{4}-\mathrm{C}_{7}$ was found in quantities ranging from 2.1 to $1432 \mathrm{ng} / \mathrm{g}(\mathrm{ppb})$, whereas $\mathrm{C}_{2}-\mathrm{C}_{3}$ ranges from 0.06 to $239 \mathrm{ng} / \mathrm{g}$ (ppb). Deeper samples from Hole 380A had more $\mathrm{C}_{4}-\mathrm{C}_{7} / \mathrm{C}_{0}$ than the shallower but older sediments at Site 381 .

There was a general increase in $\mathrm{C}_{4}-\mathrm{C}_{7}$ with depth in all three holes, but Whelan and Hunt found that the yields of $\mathrm{C}_{4}-\mathrm{C}_{7}$ at the base of Site 381 was a little larger than that at the bottom of Hole 379A, which probably is due to longer burial time at 381. The increase in yield of $\mathrm{C}_{4}-\mathrm{C}_{7}$ hydrocarbons with sediment age and with increasing temperature and depth of burial strongly indicates that the hydrocarbons are formed in situ by low temperature degradation of organic matter.

Several studies have been made of the humic compounds (Kendrick et al., Kuprin and Potapova, Huc et al., this volume). Kendrick, Hood, and Castaño found that organic matter is predominantly humic or reworked humic material. Sediments with higher contents of organic matter tend to have higher amounts of lipid-rich material, perhaps due to a better environment for preservation.

Huc, Durand, and Monin (this volume) analyzed sediments from Sites 379 and 380 for their content of humic compounds and kerogen. The humic acids show considerable variations with depth that reflected changes in source. Some of the organic compounds show a definite change with depth. For example, the hydrolyzable fraction, the humic compound content, the oxygen content of the more autochthonous-derived humic acids, and the protein-aceouslike material in the humic acids all tend to decrease with depth (similar to the results of Kuprin and Patapova). The 
more land-derived (allochthonous) humic acids do not show a decrease. These changes move the sediments towards a more kerogen status, such as typical of ancient sediments. Kerogen is already formed in the sediments studied from the deeper parts of Site 380 (Pliocene/Miocene) but the change is still in progress in material from Site 379 (Pleistocene).

Huc et al. did not note any obvious correlation of organic matter with stratigraphic units, except in black shales (sapropels) or black varves that have high organic compounds.

Kuprin and Potapova (this volume) studied the humic and fulvic acids in the sediments from Site 380 (Holes 380 and $380 \mathrm{~A}$ ). Humic compounds, as Kendrick et al. have shown, constitute a large portion of the organic matter of the Black Sea sediments. The gross composition of the organic matter from Site 380 changes with depth. In the upper part of the section, humic acids make up over $20 \%$ of the total organic content and the easily hydrolized substances $5 \%-8 \%$, whereas in the lower part of the section, these values have dropped to $5 \%-6 \%$ and 0.1 to 0.2 , respectively.

These authors conclude that the humic acid composition is influenced by sedimentation patterns (low molecular fractions of humic acids correlate with silt and sand content). The general change in composition and properties of the humic and fulvic component is taken to be a reflection of the diagenetic pattern; however, compounds within the section studied still retain their basic structural features in spite of fluctuations in their composition.

Geodekyan et al. (this volume) studied the bitumoids and other parts of the organic fraction from Site 379 and made laboratory simulation studies of organic matter transformation. They noted no relationship of bitumoid " A' ' concentration with total Corg or with depth of burial, and feel that the total concentration of bitumoids depends to a large degree on the initial type of organic matter and its past transformations. The samples contained the organic components found in rocks such as hydrocarbons, resins, asphaltenes, and insoluble matter. It is obviously impossible to reproduce in the laboratory the geochemical processes of oil and gas formation. Nevertheless, such studies can lead to understanding some of the catagenic processes. The experimental work of Godekyan et al. shows a mixture of light and heavy hydrocarbonic gas fractions with the formation of condensed aromatic and naphthene-aromatic structures. They believe that their work is supportive of the organic origin of oil and gas.

Simoneit (this volume) studied the lipid fraction from selected samples. The lipid extracts have a distribution typical for material having a terrigenous and/or lacustrine origin. Indicators of terrigenous origin are n-alkanes $\left(n-C_{25}\right.$ to $\mathrm{n}-\mathrm{C}_{33}$, odd-to-even predominance, maximum mainly at $\mathrm{n}-\mathrm{C}_{29}$ ), fatty acids ( $\mathrm{n}-\mathrm{C}_{22}$ to $\mathrm{N}-\mathrm{C}_{30}$, even-to-odd predominance, maximum at $\mathrm{n}-\mathrm{C}_{24}$ or $\mathrm{n}-\mathrm{C}_{26}$ ) and dehydrobietic acid. Values of $\delta^{13} \mathrm{C}$ for the total lipid fraction fall within ranges $\left(\delta^{13} \mathrm{C}\right.$ range from -24.9 to $\left.-29.8 \%\right)$ typical of terrestrial and some lacustrine plants and fresh-water plankton.

King and White (this volume) found some muramic acid in the Black Sea sediments. Muramic acid is an amino acid that is only found in cell wall polymers of bacteria and blue-green algae. Their data indicate bacterial densities one-tenth to one-half that found in semitropical estuarian sediments and, based on certain assumptions, the sediments may contain between $0.05 \%$ and $0.5 \%$ bacteria by weight. The distribu- tion of the microbial mass, based on the acid information, is not uniform.

\section{Hydrocarbon Potential of Black Sea Sediments}

Anders et al. (this volume) made an organic geochemical study of the Black Sea sediments. In part they were looking for similarities between the Black Sea material and that of the Eocene Green River formation. Analyses made included organic carbon, with thermal analysis (pyrolysis) hydrocarbon yield, gas chromatography for total bitumens and heptane, benzene, and benzene-methanol eluates. Their analyses show a non-linear relationship between the amount of organic carbon and the yield of volatile pyrolysis products. An interpretation of this could be that the sediments contain a mixture of two types of organic matter. They note an essentially constant minimum amount of about $0.4 \%$ Corg that is refractory and gives little or no volatile material, with pyrolysis. This component could be recycled kerogen or charcoal. The other component may come from organic matter produced in the water column or elsewhere near the location, and is a variable component of labile organic carbon.

In general, Anders et al. found that, at Site 380, the deeper chemical (calcareous and dolomitic) sediments contained higher amounts of organic matter than the shallower terrigenous units, but that no effects of depth of burial and/or age and temperature history were found on the relative amounts of the different classes of extractable organic matter. At this site the upper terrigenous sediments have n-alkanes as the predominant hydrocarbon constituents, whereas in the lower, chemical part of the section steranes (and sterenes) and pentacyclic triterpanes (and triterpenes) are the major constituents (n-alkanes are still important in the lower part of the section). They feel that the organic matter from the upper terrigenous section may have been carried in with the sediment, whereas the material in the lower part was produced at the area of deposition. The average organic carbon content is $0.9 \%$ from the terrigenous section and $1.8 \%$ from the deeper section, based on 12 samples. The average yield from pyrolysis of hydrocarbon products per unit of organic matter is about four times higher in the deeper part ofsthe section. The authors stress how this shows the importance of the depositional environment and other conditions for the preservation of organic matter that can ultimately generate hydrocarbons. They believe that although the Black Sea sediments are qualitatively similar to the Green River oil shale, they only have about $1 / 10$ the organic matter content of an economically valuable oil shale.

Erdman and Schorno demonstrate that the Black Sea sediments they studied contained enough organic matter to be considered as a potential petroleum source. They also noted that the high ratios of odd to even n-alkanes (OEP) indicate that the petroleum genesis is in a very early state, a conclusion similar to that of McIver (this volume) based on alteration indexes and ratios of hydrocarbons to bitumens. The high OEP values also indicate a large input of terrigenous material to the total organic content.

Shiskina noted the large concentrations of iodine in pore waters from Hole $379 \mathrm{~A}$ and explained this as coming from sediments deposited in a region of "halistasis" or high organic enrichment. As a result of diagenesis and consolidation, the iodine is transferred from the sediment to the pore 
fluid. This process is facilitated by temperatures of $32^{\circ}-40^{\circ}$ C. The concentration of iodine which reaches a maximum of $41.6 \mathrm{mg} / \mathrm{kg}$ is comparable to the range in oil field brines.

Kendrick, Hood, and Castaño evaluated the petroleumgenerating potential of the Black Sea (and Mediterranean) sediments in terms of their organic content and thermal history. They concluded that the sediments contain sufficient quantities of thermally active organic material to be considered as a potential petroleum source rock, although none of the material they sampled has been buried deep enough for organic matamorphism to reach the petroleum-generation stage. The authors regard the figure of $1.0 \%$ to $1.5 \%$ Corg as a minimum requirement for a petroleum source rock, but they also consider the pyrolysis hydrocarbon yield (petroleum compounds generated by heating) to be of considerable importance in producing potential source rocks. Several of the Black Sea sediment samples have sufficiently high values for both these important characteristics. Their conclusion that none of the Black Sea sediments have been heated sufficiently to reach oil-generation stage is based on the temperature measurements of Erickson and von Herzen (this volume).

Manheim (this volume) measured a "formation factor" $\left(R_{\mathrm{s}} / R_{\mathrm{w}} 8\right)$ for many samples from the Black Sea drilling. $R_{\mathrm{s}}$ is the resistivity of the rock or sediment, and $R \mathrm{w}$ is the resistivity of the enclosed pore water, both measured at a common temperature. The formation factor commonly increases with depth, generally due to sediment consolidation, cementation, reduction in the amount of connected pore space, and other factors. Variations in depth changes in the formation factor within the Black Sea cores can, in some instances, be due to the presence of clays, which, although they may have high porosity, are less permeable than other sediments. Sorting and cementation can also be important in the Black Sea sediments. The latter is especially relevant in some of the lithified limestones and carbonates from Sites 380 and 381 . Within these units, formation values in the hundreds are common; these values are an order of magnitude higher than the interbedded shales and more sandy sediments. The inverse of the formation factor is a measure of the tortuosity of the sediments, indicating the ability of dissolved chemical species to migrate through connected pore spaces.

Manheim shows that some of the deeper lithified limestones and dolomites (with high formation factors) may prevent upward migration of waters from even deeper horizons. This could be a barrier to movements of the heavier hydrocarbons, but they could accumulate in updip closures.

\section{ACKNOWLEDGMENTS}

This manuscript was reviewed by Drs. K. O. Emery and John Milliman of the Woods Hole Oceanographic Institution. I was supported during the writing of this paper by a contract with the Office of Naval Research. It should be noted that the Soviet summary manufscript by Muratov et al. was not available at the time this paper was prepared.

\section{REFERENCES}

Degens, E. T. and Ross, D. A. (Eds.), 1974. The Black Seageology, chemistry, and biolody: Am. Assoc. Petrol. Geol., Mem. 20, p. 633.

Ross, D.A., Uchupi, E., Prada, K.E., and Macllvaine, J.E., 1974a. Bathymetry and microtopography of Black Sea. In Degans, E.T. and Ross, D.A. (Eds.), The Black Sea - geology, chemistry, and biology: Am. Assoc. Petrol. Geol. Mem. 20, p. 1-10.

Ross, D.A., Uchupi, E., and Bowin, C.O., 1974b. Shallow structur of Black Sea. In Degens, E.T. and Ross, D.A. (Eds.), The Black Sea - geology, chemistry, and biology: Am. Assoc. Petrol. Geol. Mem. 20, p. 11-34.

VanEysinga, F.W.B., 1975. Geological time tables, 3rd ed.: Netherlands (Elsevier Publ. Co.). 